DOI https://doi.org/10.30525/978-9934-26-008-7.1-10

\title{
APPLICATION OF NUMERICAL METHODS OF SOLVING THE SYSTEM OF NORMAL DIFFERENTIAL EQUATIONS IN THE PROBLEMS OF ELECTRICAL ENGINEERING AND ELECTROMECHANICS
}

\author{
Kuznetsova Ye. V., Kuznetsova A. V.
}

\section{INTRODUCTION}

In connection with the existing problems of energy saving at industrial enterprises of Ukraine, more and more attention is paid to the implementation of measures that can ensure the implementation of basic technological processes with significant energy savings. When organizing power supply and electricity consumption, there is one common and quite serious task - to improve and optimize the quality of electricity in order to increase the efficiency of its use and ensure the reliability of electrical equipment.

An unregulated electric drive is widely used in many enterprises, the main equipment of which is an asynchronous motor (AM) with a shortcircuited rotor in more than $90 \%$ of cases. This is due to the simplicity of the latter, and, as a consequence, its high reliability, low cost and minimal operating costs.

As is know ${ }^{1}$, the operation of an induction motor in networks with poor quality electricity leads to negative consequences, namely: the

1 Оценка влияния качества электроэнергии на эффективность электропотребления. Гірнича електромеханіка та автоматика. Науково-технічний збірник. 2018. Випуск 100. С. 85-95.

$\alpha$-алгебра в задачах підвищення енергоефективності асинхронних двигунів, працюючих в умовах неякісної електроенергії / М.М. Трипутень, В.В. Кузнецов, С.В. Кузнецова, М.М. Трипутень, А.В. Кузнецова. Гірнича електромеханіка та автоматика. Науково-технічний збірник. 2019. Випуск 101. С. 110-114.

Kuznetsov V., Tryputen N., Kuznetsova Y. Evaluating the Effect of Electric Power Quality upon the Efficiency of Electric Power Consumption // 2019 IEEE 2nd Ukraine Conference on Electrical and Computer Engineering (UKRCON), Lviv, Ukraine, 2019. pp. 556-561. doi: 10.1109/UKRCON.2019.8879841.

Predicative form of the energy-economic model of an asynchronous motor / M. Tryputen, V. Kuznetsov, Y. Kuznetsova, M. Tryputen, A. Kuznetsova, R. Sklyar. Системні технології. 2019. Вип. 2. С. 33-41. 
temperature of the motor windings increases; its service life decreases; technical and economic indicators of the latter, such as power factor and efficiency factor, decrease; losses increase and the amount of reactive power consumed increases. The analysis of researches allows to draw a conclusion that work of electromechanical converters in the conditions of low-quality electric power leads to decrease in working capacity and reliability of such class of the equipment ${ }^{2}$.

However, the published research results do not contain an economic assessment of the resulting losses. The influence of low-quality electricity on the engine operation considered in them does not affect the main thing - the financial aspect of the problem. Cost issues have not been studied so far and, as a result, it is not possible to make a comparative assessment of the economic damage associated with poor quality electricity and the costs required to ensure this quality.

The share of electricity costs is the dominant component of the total cash required for the operation of electrical equipment. According to various estimates, it is $75-80 \%^{3}$. Therefore, even a small increase in losses associated with the deterioration of electricity quality indicators

2 Кузнецов В.В., Кузнецова А.В., Трипутень М.Н. Основные причины отклонения показателей качества электроэнергии от нормируемых. Енергозбереження та енергоефективність: зб. тез міжнар. наук.-практ. конф. (Дніпро. НТУ ДП. 28-29 листопада 2019 р.). Дніпро, 2019. С. 12-13.

Кузнецов В.В. Кузнецова А.В., Трипутень М.Н. Количественная оценка показателей качества электроэнергии в цеховых сетях предприятий. Енергозбереження та енергоефективність: зб. тез міжнар. наук.-практ. конф. (Дніпро. НТУ ДП. 28-29 листопада 2019 р.). Дніпро, 2019. С. 14-15.

Кузнецов В.В. Трипутень Н.М. Кузнецова А.В., Трипутень М.Н. О нормировании показателей качества электроэнергии. Енергозбереження та енергоефективність : зб. тез міжнар. наук.-практ. конф. (Дніпро. НТУ «ДП». 28-29 листопада 2019 р.). Дніпро, 2019. С. 16-17.

Serdiuk T., Kuznetsov V., Serdiuk K., Nikolenko A., Kuznetsova Y., Kuznetsova A. Improvement of Technical Service of Track Circuits. 2019 IEEE 6th International Conference on Energy Smart Systems, ESS 2019 - Proceedings, pp. 28-32. DOI: $10.1109 /$ ESS.2019.8764191.

Characteristic layouts of distribution networks with the analysis of voltage deviations and expediency of its control / V. Kovalenko, S. Levchenko, M. Tryputen, V. Kuznetsov, M. Tryputen, O. Gorodny, A. Kuznetsova, Ye. Kuznetsova. Technical sciences and technologies. 2019. 3 (17). pp. 209-218.

3 United States Industrial Electric Motor Systems Market Opportunities Assessment December 2002 - Режим доступа. URL : https://www.energy.gov/ sites/prod/files/2014/04/f15/mtrmkt.pdf. (дата звернення: 01.05.2020).

Annual Electric Power Industry Report, Form EIA-861 detailed data files. URL : https://www.eia.gov/electricity/data/eia861. (дата звернення: 01.05.2020). 
(EQI) leads to a significant increase in annual maintenance costs of electric drives.

The aim of the monograph section is the synthesis of a mathematical analogue of an induction motor, which allows the staff of the enterprise to quickly assess the energy performance of AM operating in a network with low-quality electricity.

To achieve the goal in the monograph section the following tasks are set and solved:

1) improvement of the electromagnetic model of BP, which allows to determine its energy performance with an arbitrary change over time in the quality of electricity;

2) calculation of energy performance of an induction motor by solving a system of differential equations given in the Cauchy form, which describe its work in the time domain by known numerical methods, namely: Euler method, modified Euler method and Runge Kutta method IV order;

3) search for optimal values of the harmonic spectrum of the input voltage according to a given criterion $\eta_{\mathrm{AM}} \rightarrow$ max with given restrictions on the amplitudes of the harmonic components of the input voltage.

\section{Theoretical and methodological fundamentals of asynchronous motor functioning in conditions of poor quality electricity}

\subsection{About normative documents regulating quality of electric energy and necessity of rationing of its indicators}

As is known ${ }^{4}$, electromagnetic compatibility (EMC) of technical means considers the processes occurring in electrical complexes and systems in terms of generating electromagnetic interference, their impact on electrical equipment, the degree of protection and correction of adverse effects. The emergence of new devices for conversion technology, the modernization of an increasing number of industrial electrical installations, in particular, the use of adjustable electric drive, lead to a decrease in the quality of electricity in the supply networks of enterprises. This necessitates the strengthening of electromagnetic compatibility requirements for industrial plants. Standardization of

4 Жаркин А.Ф., Палачев С.А. Нормативное регулирование качества электроэнергии в системах электроснабжения общего назначения Украины и стран Евросоюза. Технічна електродинаміка. 2007. № 6. С. 54-60. 
electricity quality indicators in such conditions is one of the main issues of this problem.

Electricity quality indicators (EQI), regulated by state standards, are the starting point in almost all areas related to electrical installations. This applies to the design of new facilities, and commissioning, research of electrical equipment, the decision to upgrade and others.

The international normative basis for the assessment of electromagnetic compatibility of electrical installations is the wellknown European standard EN 50160: "Characteristics of voltage supplied by general purpose distribution systems" (1994), as well as the standard of the International Electrotechnical Commission (IEC) 10002 - 4: Electromagnetic compatibility. EMC levels at industrial facilities for low-frequency conduction interference.

EQI in the power supply systems of industrial enterprises are determined by the mode of operation of electrical installations that introduce distortion, and therefore are constantly changing. Therefore, in GOST 13109-97 Electricity. Requirements for the quality of electricity in general purpose electrical networks provides a comprehensive methodology for assessing the quality of electricity, based on the assessment of energy performance of the distortion. Normalized EQIs are integrated indicators that reflect the degree of negative impact of distortion of electricity on the technical and economic characteristics of electrical equipment. The maximum allowable values of the electricity quality indicator are selected for technical and economic reasons and the impact of distortion on the reliability of electrical equipment.

Thus $^{5}$, the main document ${ }^{6}$ in force in Ukraine regulates the following indicators of electricity quality: voltage deviation $\delta \mathrm{U}_{\mathrm{y}}$; the magnitude of the voltage change (or the amplitude of voltage fluctuations (VF)); intensity (dose) of flicker $P_{t}$; the coefficient of curvature of the sinusoid of the curve of linear (phase) voltage $K_{U}$; the coefficient of the n-th harmonic component of the voltage $K_{U(n)}$; reverse

5 Жаркин Л.Ф., Палачев С.А. и др. Нормативно-правовое регулирование вопросов качества электроэнергии в Украине и странах Евросоюза. Техн. електродинаміка. Тем. вип. "Силова електроніка та енергоефективність». 2007. Ч. 1. C. 74-77.

6 ГОСТ 13109-97 Электрическая энергия. Совместимость технических средств электромагнитная. Нормы качества электрической энергии в системах электроснабжения общего назначения. URL : http://docs.cntd.ru/document/ 1200006034 (дата звернення: 01.05.2020). 
voltage asymmetry coefficient $K_{2 U}$ and zero $K_{0 U}$ sequence; duration of voltage failure $K_{d v}$; voltage pulse $U_{p u l s}$; temporary overvoltage factor $K_{o v}$; frequency deviation. Therefore, consider methods for calculating only the main indicators of electricity quality associated with the most common distortions of the network.

The asymmetry of voltages of a three-phase network is characterized by the coefficient of their reverse sequence $K_{2 U}, \%$, which is determined by the ratio of the current value of the voltage of the reverse sequence of the fundamental frequency of the three-phase voltage system $U_{2}$ to the nominal value of the phase voltage $\mathrm{U}_{\text {nom }}$ :

$$
K_{2 U}=\frac{U_{2}}{U_{n o m}} \cdot 100 .
$$

In addition, the value of the zero sequence coefficient is normalized $K_{0 U}, \%$, which is determined by the ratio of the voltage of the zero sequence of the fundamental frequency $\mathrm{U}_{0}$ to the nominal value of the phase voltage $\mathrm{U}_{\text {nom }}$ :

$$
K_{0 U}=\frac{U_{0}}{U_{\text {nom. }}} \cdot 100 .
$$

Non-sinusoidal voltage is characterized by the value of the curvature coefficient of its curve $K_{U}, \%$, which is determined by the ratio of the current value of the higher harmonics $U_{n}$ to rated voltage:

$$
K_{U}=\frac{1}{U_{n o m}} \sqrt{\sum_{n=2}^{N} U_{n}^{2}} \cdot 100,
$$

$U_{n}$ - the effective value of the voltage of the $\mathrm{n}^{\text {th }}$ harmonic; $\mathrm{N}=22-$ the number of the last of the considered harmonics. The permissible and maximum permissible value $K_{U}$ depends on the voltage class.

In addition to the non-sinusoidal coefficient, the coefficients of each harmonic component up to the 22 nd separately are also normalized. The latter are defined by the expression:

$$
K_{U(n)}=\frac{U_{n}}{U_{\text {ном }}} \cdot 100,
$$

And their allowable and maximum allowable values are also normalized depending on the voltage class.

Thus, the quality of electricity is determined by the set of its indicators, at which the electrical receivers can work properly and 
perform their functions. At deviations of their values from admissible, normal work of electromechanical converters is complicated or is possible only at considerable reduction of loading. It should also be noted that the reduction of the efficiency of this equipment often occurs at the values of EQIs in the ranges allowed by the standards.

\subsection{Estimation of influence of quality of the electric power on indicators of work of induction motors}

To date, extensive experience has been accumulated in the field of studying the impact of power quality on the operation of induction motors with short-circuited rotor ${ }^{7}$. So, for example, when studying the questions connected with a quantitative estimation of damage of the above-stated electromechanical converters working in the conditions of asymmetry of supply voltage, authors of work ${ }^{8}$ have concluded that at value $\mathrm{K}_{2 \mathrm{U}}=3,5 \%$ the temperature of the motor windings rises by $25 \%$, and in $^{9}$ it was found that when increasing the coefficient of stress asymmetry in the reverse sequence $\mathrm{K}_{2 \mathrm{U}}$ up to $4 \%$ the service life of the induction motor is reduced by half.

In works ${ }^{10}$ it is indicated that during the operation of induction motors in conditions of non-sinusoidal supply voltage there are such negative factors as a decrease in power factor and torque on the shaft of the electric machine. It is established that every $2.5 \%$ increase in supply voltage leads to an increase in losses in the induction motor by 3 ... 3.9\%

7 Кузнецов В.В., Трипутень Н.М., Кузнецова А.В., Трипутень М.Н. Динамическая электромагнитная модель асинхронного двигателя, работающего в условиях некачественной электроэнергии. Матеріали Міжнародної науковотехнічної конференції Інформаційні технологї в металургї та машинобудуванні. 26-28 березня 2019 року м. Дніпро. С. 87.

${ }^{8}$ Beaty H. Motors reguire voltage limits. Elec.World. Vol. 189. No. 5.1978. P. 52-53.

${ }^{9}$ Shaller D.,Seidler E. Berechnung des Einflusses einer Zweiphasenlast auf die Strom - und Spannungsunsymmetrie in Energieversorgungsnetzen. Mitt.Inst.Energ. H. 70. 1965. S. 586-596.

10 Марданов Фарит Халитович Показатели качества электроэнергии, влияющие на работу электрооборудования города. Проблемы науки. 2018. № 5(29). URL : https://cyberleninka.ru/article/n/pokazateli-kachestva-elektroenergiivliyayuschie-na-rabotu-elektrooborudovaniya-goroda (дата обращения: 02.05.2020). 
and an increase in reactive power consumption by almost 5\%, which negatively affects the energy efficiency of its operation ${ }^{11}$.

It is also known ${ }^{12}$ that in the presence of distortions of supply voltage, special attention should be paid to electric drive systems, as this leads to a decrease in their reliability and efficiency and, consequently, to a significant reduction in technical and economic performance of many industries. When the quality of electricity decreases, there is an increase in power losses in induction motors, which causes their increased heating. And this, in turn, contributes to the intensive aging of the insulation and, as a result, its breakdown.

Thus, during the year, the electric machine converter of low and medium power consumes electricity, which is 3-5 times more expensive than the engine ${ }^{13}$. At the same time, up to $75 \%$ of electricity in production is consumed by an induction motor of this power (up to $75 \mathrm{~kW}$ ). Therefore, reducing the efficiency of the engine, due to the fact that it is powered by poor quality electricity, even one percent means a significant economic loss for any enterprise.

Based on the above, the study area is the task of assessing the reduction of energy performance of an induction motor caused by poor quality electricity in the power supply systems of industrial enterprises, due to the following reasons:

1. Practice shows ${ }^{14}$ that in most enterprises the permissible levels of at least one of the standardized indicators of electricity quality are exceeded. At the same time, while the integral indices of symmetry and

11 Луговой А.В. Вопросы практического энергосбережения промышленных предприятий. Вісник КДПУ. -1998. Випуск 1(4). С. 73-77.

12 Зиновкин В.В. Моделирование добавочных потерь в электрооборудовании системы электротехнического комплекса при несинусоидальных токах. Вісник КДПУ. Випуск 4/2007(45). С. 49-52.

13 Energiesparen mit elektrischen Antrieben. - Frankfurt am Main: Zentralverband Elektrotechnik- und Elektronikindustrie e.V. 2007. S. 24; Motoren und geregelte Antriebe. Frankfurt am Main: Zentralverband Elektrotechnik- und Elektronikindustrie e.V. 2010. S. 16.

${ }^{14}$ Kuznetsov V., Tryputen N., Kuznetsova Y. Evaluating the Effect of Electric Power Quality upon the Efficiency of Electric Power Consumption // 2019 IEEE 2nd Ukraine Conference on Electrical and Computer Engineering (UKRCON), Lviv, Ukraine, 2019. pp. 556-561. doi: 10.1109/UKRCON.2019.8879841; Кузнецов В. В. Кузнецова А. В., Трипутень М. Н. Количественная оценка показателей качества электроэнергии в цеховых сетях предприятий. Енергозбереження та енергоефективність: зб. тез міжнар. наук.-практ. конф. (Дніпро. НТУ «ДП». 28-29 листопада 2019 р.). Дніпро, 2019. С.14 -15. 
sinusoidality are normal, the coefficients of the individual harmonic components significantly exceed the maximum allowable values.

2. At the same levels of power quality indicators, the spectral composition of the voltage can change significantly, as the latter is determined by the type of voltage-distorting electrical receivers and the mode of their operation.

Thus $^{15}$ it is necessary to develop a model of an induction motor efficient and adequate for any, including distorted stator supply voltage. The model should allow to analyze transient and established modes, to receive data on component losses in the engine. The data obtained with the help of the model will serve as the initial data for estimating the additional costs for electricity during the operation of induction motors in the conditions of poor-quality EQI.

It should be borne in mind that the problem of the negative impact of low-quality electricity is complex, covering the reliability of electrical equipment, the development of measures to ensure its smooth operation throughout the regulatory life. Therefore, when considering such issues it is necessary to take into account the non-stationary indicators of electricity quality over time.

\section{Development of a dynamic electromagnetic model of an asynchronous motor operating in conditions of poor quality electricity}

\subsection{Requirements for the induction motor model}

As is known from works ${ }^{16}$, mathematical analogues of induction motors are widely used to assess the effectiveness of control laws, study electromagnetic processes and predict the energy performance of their work. However, the situation is complicated when the simulation must take into account the quality of electricity, such as asymmetry and non-

15 Кузнецов В.В., Трипутень Н.М., Кузнецова А.В., Трипутень М.Н. Разработка динамической электромагнитной модели асинхронного двигателя, работающего в условиях некачественной электроэнергии. Матеріали Міжнародної науково-технічної конференції Інформаційні технологї $в$ металургї та машинобудуванні. 26-28 березня 2019 року м. Дніпро. С. 88.

16 Кузнецова А.В., Сердюк Т.М. Електромагнітна сумісність пристроїв залізничної автоматики 3 системою тягового електропостачання. Сучасні інформаційні та комунікаційні технологї на транспорті, в промисловості $i$ ocвimi: Тези XII Міжнародної науково-практичної конференції (Дніпро, 12-13 грудня 2018 р.). Дніпро : ДНУЗТ, 2018. С. 37. 
sinusoidal electrical quantities. The problem is that given the assumptions made in this case, the BP model itself often becomes inadequate. If more complex models are used, the description of the processes is so complicated that finding the necessary dependencies becomes too problematic.

However, the assumption of symmetry and sinusoidal supply voltage is now, in fact, unfounded, because the quality of electricity in the shops of industrial enterprises almost always does not meet the necessary requirements ${ }^{17}$. Therefore, one of the most important tasks set in the work is to develop a mathematical analogue of an induction motor that predicts its energy performance when the quality of the supply voltage changes.

We formulate the requirements for the type, functionality, characteristics and composition of the input values, which must meet the model of an induction motor, which we are developing ${ }^{18}$ :

1. The AM model must be operational at any form of voltage on the stator, including non-sinusoidal and asymmetry. This requirement is necessary for most currently used mathematical analogues of the considered engines.

2. The model we are developing must be adequate in both the established and transient modes, which are related to the change of load, quality of electricity, control influence.

3. The initial parameters of the model should be:

- instantaneous values of stator and rotor currents of an induction motor, their spectrum;

- active $(\mathrm{P})$, reactive $(\mathrm{Q})$ and full $(\mathrm{S})$ powers, including their share, which is associated with voltage distortions from the stator, which corresponds to the real indicators of power quality;

- efficiency $(\eta \%)$ and power factor $(\cos \varphi)$;

17 Оценка влияния качества электроэнергии на эффективность электропотребления / В.В. Кузнецов, Е.В. Кузнецова, А.В. Кузнецова. Гірнича електромеханіка та автоматика. Науково-технічний збірник. 2018. Випуск 100. C. 85-95; Kuznetsov V., Tryputen N., Kuznetsova Y. Evaluating the Effect of Electric Power Quality upon the Efficiency of Electric Power Consumption // 2019 IEEE 2nd Ukraine Conference on Electrical and Computer Engineering (UKRCON), Lviv, Ukraine, 2019. pp. 556-561. doi: 10.1109/UKRCON.2019.8879841.

${ }^{18}$ Kuznetsov V., Kuznetsova A., Truputen M. Dynamic electromagnetic model of asynhronous motor operating in terms of poor-quality electric power.// Компьютерне моделювання та оптимізація складних систем (КМОСС-2019): матеріали V Міжнародної науково-технічної конференції (м. Дніпро, 6-8 листопада 2019). Дніпро : Баланс-Клуб, 2019. С. 74-75. 
- components of individual losses in the motor: losses in the stator copper $\left(\Delta \mathrm{P}_{\mathrm{M} 1}\right)$, in the rotor copper $\left(\Delta \mathrm{P}_{\mathrm{M} 2}\right)$ in steel $\left(\Delta \mathrm{P}_{\mathrm{C}}\right)$;

- speed $(\omega)$ and electromagnetic torque $(\mathrm{M})$ of AM depending on the load on the shaft, including their spectral characteristics.

Thus, the model we are developing should provide the full amount of data needed to study the operation of an induction motor operating in low-quality electricity, in order to assess the electromagnetic component, taking into account the economic damage that occurs.

\subsection{Analysis of existing models of induction motor}

Let us evaluate the possibility of using known mathematical analogues of an induction motor with a short-circuited rotor for this purpose or compiling a single combined model based on them. There are two approaches to modeling an electromechanical energy converter: based on field theory and the theory of electric circuits, based, respectively, on the equations of Maxwell and Kirchhoff. But the most advanced method of process analysis currently used in the considered energy converter ${ }^{19}$ is based on a combination of these approaches, combining these two theories. In this case, based on the picture of the field in the air gap of the electric machine, the equations for voltages are formed, and then through the current or flux coupling the equations for the electromagnetic moment are written.

To date, there are fairly complete mathematical models of asynchronous motors. The behavior of which in different operating conditions is considered in already classical studies ${ }^{20}$, but the issue of modeling the work of AM pressure when they are supplied with lowquality electricity has remained unresolved.

The most common mathematical analogue of the model of asynchronous electromechanical energy converter is given in work ${ }^{21}$. It is a spatial model of a three-phase idealized machine (Fig. 1a), based on a number of assumptions: the latter is bipolar, has a smooth air gap, all its parameters are linear, and the supply voltage is sinusoidal.

19 Копылов И.П. Математическое моделирование электрических машин. Москва : Наука, 2001. 327 с.

20 Копылов И.П. Математическое моделирование электрических машин. Москва : Наука, 2001. 327 с. Ковач К. Переходные процессы в машинах переменного тока. Москва-Ленинград : Госэнергоиздат, 1963. 744 с.

21 Копылов И.П. Математическое моделирование электрических машин. Москва : Наука, 2001. 327 с. 

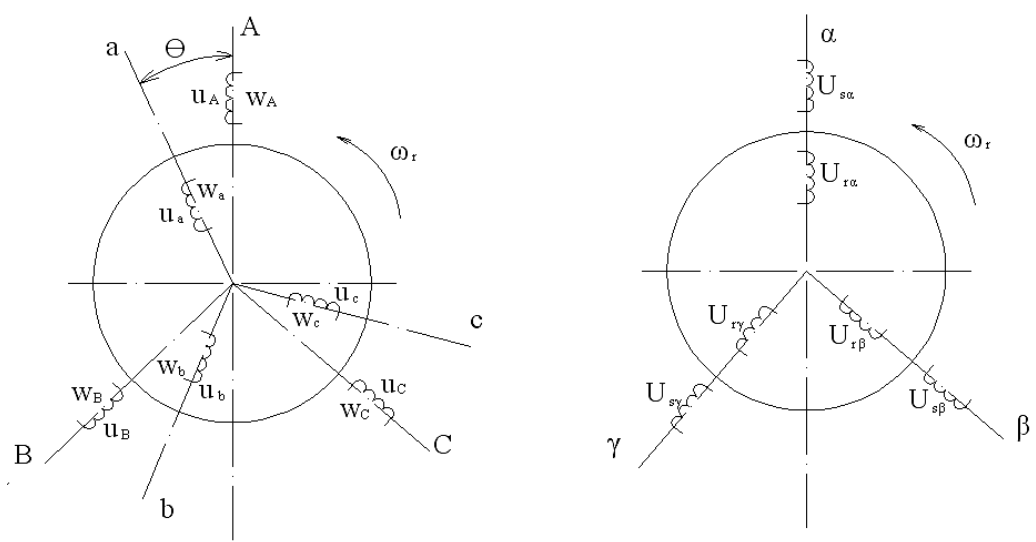

Fig. 1. Spatial models of a three-phase idealized asynchronous machine with unconverted (a) and braked (b) coordinate systems

In fig. 1 (a) presents three windings of the stator and rotor with the number of turns $w_{\mathrm{A}}, w_{\mathrm{B}}, w_{\mathrm{C}}$ and $w_{\mathrm{a}}, w_{\mathrm{b}}, w_{\mathrm{c}}$ respectively, shifted by $120^{\circ}$. In an unconverted coordinate system, when moving the windings, the mutual inductances between them change, and the derivative angle between the axes of the stator and the rotor over time gives the angular velocity of the rotor $-(\mathrm{d} \theta / \mathrm{dt})=\omega_{\mathrm{r}}$.

For the considered machine in the unconverted coordinate system $A$, $B, C, a, b, c$ a fair system of differential equations of the form ${ }^{22}$ :

$$
\left.\begin{array}{c}
u_{A}=\frac{d \Psi_{A}}{d t}+i_{A} R_{A} ; u_{B}=\frac{d \Psi_{B}}{d t}+i_{B} R_{B} ; \\
u_{C}=\frac{d \Psi_{C}}{d t}+i_{C} R_{C} ; u_{a}=\frac{d \Psi_{a}}{d t}+i_{a} R_{a} ; \\
u_{b}=\frac{d \Psi_{b}}{d t}+i_{b} R_{b} ; u_{c}=\frac{d \Psi_{c}}{d t}+i_{c} R_{c} ; \\
M_{c}+J \frac{d \omega_{\mathrm{r}}}{d t}=M_{\ni},
\end{array}\right\}
$$

where $R$ - active resistance of stator and rotor phase windings; $\Psi$ - the resulting flux couplings of these windings. Here, the flux

22 Копылов И.П. Математическое моделирование электрических машин. Москва : Наука, 2001. 327 с. 
coupling of one, such as phase A, depends on the currents and other phases of the stator and rotor:

$$
\Psi_{A}=i_{A} L_{A}+i_{B} M_{A B}+i_{C} M_{A C}+i_{a} M_{A a}+i_{b} M_{A b}+i_{c} M_{A c} .
$$

By analogy, flux couplings are recorded for the other five circuits.

In this coordinate system of inductance (L), the mutual inductances (M) in the equation for flux coupling are periodic coefficients that change according to the harmonic law when the rotor of the machine rotates. To eliminate this, the transition to the so-called braked coordinate system, where the circular field in the air gap is represented by the resulting vectors.

The spatial model of a three-phase idealized machine in a braked three-phase coordinate system is presented in Fig. 2.1b. The equation corresponding to this model in the coordinates $\alpha, \beta, \gamma$, fixed relative to the stator, have the following form:

$$
\left.\begin{array}{l}
u_{s a}=\frac{d \Psi_{s a}}{d t}+i_{s a} r_{s a} ; \\
u_{s \beta}=\frac{d \Psi_{s \beta}}{d t}+i_{s \beta} r_{s \beta} ; \\
u_{s \gamma}=\frac{d \Psi_{s \gamma}}{d t}+i_{s \gamma} r_{s \gamma} ; \\
u_{r a}=\frac{d \Psi_{r a}}{d t}+i_{r a} r_{r a}+\omega_{r} \frac{\left(-\Psi_{r \gamma}+\Psi_{r \beta}\right)}{\sqrt{3}} ; \\
u_{r \beta}=\frac{d \Psi_{r \beta}}{d t}+i_{r \beta} r_{r \beta}+\omega_{r} \frac{\left(-\Psi_{r a}+\Psi_{r \gamma}\right)}{\sqrt{3}} ; \\
u_{r \gamma}=\frac{d \Psi_{r \gamma}}{d t}+i_{r \gamma} r_{r \gamma}+\omega_{r} \frac{\left(-\Psi_{r \beta}+\Psi_{r \alpha}\right)}{\sqrt{3}} .
\end{array}\right\}
$$


Flux linkages:

$$
\left.\begin{array}{l}
\Psi_{s a}=i_{s a} L_{s a}-0.5 M i_{s \beta}-0.5 M i_{s \gamma}+\left(i_{r a}-0.5 i_{r \beta}-0.5 i_{r \gamma}\right) M ; \\
\Psi_{s \beta}=i_{s \beta} L_{s \beta}-0.5 M i_{s \gamma}-0.5 M i_{s a}+\left(i_{r \beta}-0.5 i_{r a}-0.5 i_{r \gamma}\right) M ; \\
\Psi_{s \gamma}=i_{s \gamma} L_{s \gamma}-0.5 M i_{s a}-0.5 M i_{s \beta}+\left(i_{r \gamma}-0.5 i_{r a}-0.5 i_{r \beta}\right) M ; \\
\Psi_{r a}=i_{r a} L_{r a}-0.5 M i_{r \beta}-0.5 M i_{r \gamma}+\left(i_{s a}-0.5 i_{s \beta}-0.5 i_{s \gamma}\right) M ; \\
\Psi_{r \beta}=i_{r \beta} L_{r \beta}-0.5 M i_{r \gamma}-0.5 M i_{r a}+\left(i_{s \beta}-0.5 i_{s a}-0.5 i_{s \gamma}\right) M ; \\
\Psi_{r \gamma}=i_{r \gamma} L_{r \gamma}-0.5 M i_{r a}-0.5 M i_{r \beta}+\left(i_{s \gamma}-0.5 i_{s a}-0.5 i_{s \beta}\right) M .
\end{array}\right\}
$$

When there is electromagnet energy, this electromagnetic energy is concentrated in the repeated gap:

$$
W e=0.5 \sum_{k=1}^{n} \psi_{k} \times i_{k},
$$

and electromagnetic torque

$$
M_{e}=\frac{\sqrt{3}}{2} p M\left(i_{r \gamma} i_{s a}+i_{r a} i_{s \beta}+i_{r \beta} i_{s \gamma}-i_{r \beta} i_{s a}-i_{r \gamma} i_{s \beta}-i_{r a} i_{s \gamma}\right) .
$$

This system consists of fourteen equations, in which the dependent variables are six currents and flux couplings, electromagnetic torque and speed. The system in the general case is nonlinear.

This model, as mentioned in works ${ }^{23}$, should be used to study an asynchronous electric machine in dynamic mode at sinusoidal voltage. To analyze the same set mode, as a limit case of dynamic, the equations for voltages can be obtained from the original equations of electromechanical transformation by replacing the differentiation operator $\mathrm{d}(\mathrm{)}) \mathrm{dt}$ on $\mathrm{j} \omega$.

The disadvantage of this model is that it is designed to power an induction motor only from a symmetrical system of sinusoidal voltage. With voltage asymmetry, it is necessary to decompose them into a straight, inverted and zero sequence, and consider the moment on the shaft as the sum of each of these sequences. Thus, to analyze the operation of an induction motor under the conditions of its supply of low-quality electricity requires a significant complication of the original model.

23 Копылов И.П. Математическое моделирование электрических машин. Москва : Наука, 2001. 327 с. 
In works ${ }^{24}$ the problems which are connected with nonlinearity of parameters of the electromechanical converter that as a result promotes identification of the last and definition of a resource of the car are considered. According to the authors, the models they use are suitable for electric machines that have been repaired and are in intensive use. They are also not of particular interest due to the inconsistency of the research task.

Of interest are the works ${ }^{25}$, where the author proposed a mathematical model that describes an induction motor with a short-circuited rotor as an object of regulation. But it is made with the assumption that the electrical parameters of the machine are symmetrical, and the voltage at its inputs is sinusoidal. The specified mathematical analogue allows to carry out only the partial analysis of losses in the electromechanical converter.

In most cases, the development of mathematical models of induction motors does not take into account the saturation of the magnetic circuit and the loss in steel. In works ${ }^{26}$ it is shown that at the specified assumptions it is not possible to reach high accuracy of calculations at modeling. Thus, the task of developing a mathematical model of an induction motor taking into account the saturation of the magnetic circuit and losses in steel is relevant.

24 28. Оценка качества преобразования энергии в электрических машинах с учетом параметров питающего напряжения / А.П. Черный, А.П. Калинов, В.А. Киричков. Вісник КДПУ. 2007. Випуск 4/2007 (45). Частина 1. С. 67-69; Определение послеремонтной паспортной мощности асинхронного двигателя с короткозамкнутым ротором / Д.И. Родькин, И.Н. Здор, В.В. Прус. Проблемь создания новых машин и технологий. Сб. научных трудов КГПИ. 2000. Выпуск 1/2000 (8). С. 65-71; Эквивалентизация потерь асинхронных двигателей при динамическом нагружении / Д.И. Родькин, В.А. Мосьпан. Проблемы создания новых машин $и$ технологий. Сб. научных трудов КГПИ. 2000. Выпуск 1/2000 (8). С. 96-107.

25 Математическая модель для исследования трехфазного асинхронного двигателя с короткозамкнутым ротором как объекта регулирования им для прямого процессорного управления / Т.В. Войнова. Электротехника. 1998. № 6. С. 51-61; Программное обеспечение для моделирования трехфазного асинхронного двигателя с короткозамкнутым ротором в составе системы управления электроприводами и для бездатчикового измерения регулируемых переменных. Электротехника. 2000. № 1. С. 19-25.

26 Анализ точности математической модели трехфазного асинхронного двигателя / В. Г. Макаров. Изв. вузов: Проблемь энергетики. Казань : КГЭУ. 2010. № 11-12. С. 115-125; Анализ методов учета нелинейности магнитопровода и потерь в стали в математической модели асинхронного двигателя / В.Г. Макаров, В.А. Матюшин. Вестник Казан. технол. ун-та. 2010. № 11. С. 171-179. 
From the point of view of increasing the energy efficiency of an asynchronous electric drive, it is important to develop algorithms for optimal current control of an induction motor according to the criterion of minimum power of total losses taking into account the saturation of the magnetic circuit ${ }^{27}$.

In our case, the mathematical model of the electromechanical converter operating in the conditions of asymmetry of primary voltages, considered in $^{28}$, where the author applied the method of symmetric components, deserves special attention. The system of asymmetric primary stator voltages $\left(\underline{U}_{A 1}, \underline{U}_{B 1}, \underline{U}_{C l}\right)$ is represented as the sum of the components of the forward $\left(\underline{U}_{A 11}, \underline{U}_{B 11}, \underline{U}_{C 11}\right)$ and inverse $\left(\underline{U}_{A 12}, \underline{U}_{B 12}, \underline{U}_{C 12}\right)$ sequences. In this case, the components of the zero sequence are not considered, because it is assumed that the motor windings are connected to the star, and, thus, there is no circuit for the flow of currents in this sequence. The calculation of these components is carried out according to known dependencies:

$$
\begin{aligned}
& \underline{\mathrm{U}}_{\mathrm{A} 11}=\underline{\mathrm{U}}_{11}=\frac{\left(\underline{\mathrm{U}}_{\mathrm{A} 1}+\mathrm{a} \underline{\mathrm{U}}_{\mathrm{B} 1}+\mathrm{a}^{2} \underline{\mathrm{U}}_{\mathrm{Cl}}\right)}{3} ; \\
& \underline{\mathrm{U}}_{\mathrm{A} 12}=\underline{\mathrm{U}}_{12}=\frac{\left(\underline{\mathrm{U}}_{\mathrm{A} 1}+\mathrm{a}^{2} \underline{\mathrm{U}}_{\mathrm{B} 1}+\mathrm{a} \underline{\mathrm{U}}_{\mathrm{Cl}}\right)}{3},
\end{aligned}
$$

where $\mathrm{a}=\mathrm{e}^{\mathrm{j} 2 \pi / 3}$. The currents in the stator winding also represent the sum of these sequences $\left(\underline{\mathrm{I}}_{\mathrm{A} 11}=\underline{\mathrm{I}}_{\mathrm{A} 11}, \underline{\mathrm{I}}_{\mathrm{B} 11}, \underline{\mathrm{I}}_{\mathrm{C} 11} ; \underline{\mathrm{I}}_{\mathrm{A} 12}=\underline{\mathrm{I}}_{12}, \underline{\mathrm{I}}_{\mathrm{B} 12}, \underline{\mathrm{I}}_{\mathrm{C} 12}\right)$, which are due to the considered symmetric stress systems, respectively.

In this work, the current of the direct sequence $\underline{I}_{11}$ in phase «A» of the stator is found using the substitution circuit of the asynchronous machine, which is shown in Fig. 2. a, where $s_{1}=\left(\Omega_{1}-\Omega\right) /\left(\Omega_{1}\right)-$ is the sliding of the rotor relative to the field of this sequence. Here $\Omega_{1}$ and $\Omega$ - angular velocities of the specified field and rotor.

The current of the direct sequence $\left(\underline{I}_{11}\right)$ is determined by the corresponding voltage system and the resistance of the stator winding.

27 Оптимальное управление токами электрических машин / В.Г. Макаров, В.А. Матюшин. Вестник Казан. технол. ун-та. Казань : КГЭУ. 2010. № 11. C. $186-195$.

28 Иванов-Смоленский А.В. Электрические машины. В 2-х т. Том 1 : Учебник для вузов. 2-е изд., перераб. и доп. Москва : Издательство МЭИ, 2004. $656 \mathrm{c}$. 


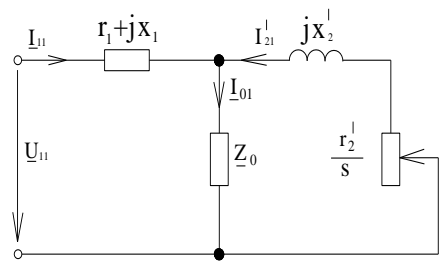

a)

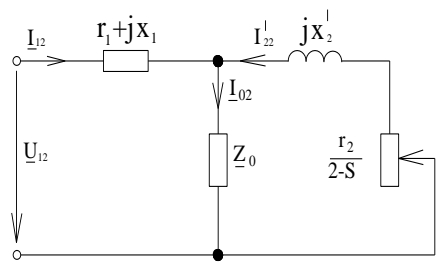

b)

Fig. 2. Scheme of replacement of an induction motor for the voltage of the forward (a) and inverse (b) sequence

To calculate the reverse sequence current $\underline{I}_{12}$ in phase " $\mathrm{A}$ " of the stator, the substitution scheme shown in Fig. 2.b, which differs from the previous one in that it introduced the sliding of the rotor relative to the field of the reverse sequence $\mathrm{s}_{2}=\left(-\Omega_{1}-\Omega\right) / \Omega_{1}=2-\mathrm{s}$, where $\left(-\Omega_{1}\right)$ - the angular velocity of the latter. After calculating the currents $\underline{I}_{11}$ and $\underline{I}_{12}$ in phase "A", as their vector sum find the total currents in each of the stator phases.

The resulting torque of the induction motor $(\mathrm{M})$ when the voltage symmetry is violated is defined as the sum of the moments $\mathrm{M}_{1}$ and $\mathrm{M}_{2}$, associated with the voltage of the forward and reverse sequences, respectively. This model, although it allows you to perform an analysis of the energy efficiency of the engine, but only in the case of asymmetry of the supply voltage.

Also noteworthy is the mathematical analogue of AM, described in the works ${ }^{29}$. Here the operation of the machine at non-sinusoidal asymmetric supply voltage in the set mode is investigated.

The author replaces the differential equations of a three-phase asynchronous machine in the axes $\alpha-\beta-0$ with a complex form:

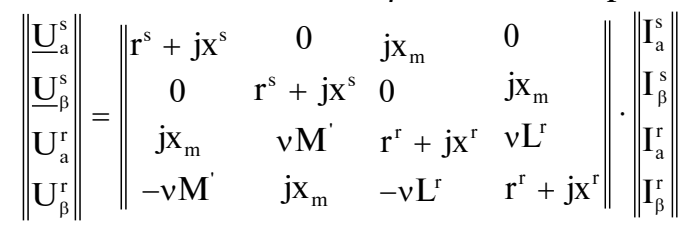

Then the components of the forward and reverse sequences of voltages and currents along the axes $\alpha-\beta$ are introduced. In the absence of zero sequence, the following expressions are obtained:

${ }^{29}$ Копылов И.П. Щедрин О.П. Расчет на ЦВМ характеристик асинхронных машин. Москва : Энергия. 1973. 212 с. 


$$
\begin{aligned}
& \underline{\mathrm{U}}_{\mathrm{a}}=\underline{\mathrm{U}}_{\text {пр }}+\underline{\mathrm{U}}_{\text {обр }} ; \underline{\mathrm{I}}_{\mathrm{a}}=\underline{\mathrm{I}}_{\mathrm{np}}+\underline{\mathrm{I}}_{\text {обр }} ; \\
& \underline{\mathrm{U}}_{\mathrm{b}}=\mathrm{a}^{2} \underline{\mathrm{U}}_{\text {пр }}+\underline{\mathrm{a}}_{\text {обр }} ; \underline{\mathrm{I}}_{\mathrm{b}}=\mathrm{a}^{2} \underline{\mathrm{I}}_{\mathrm{np}}+\mathrm{a} \underline{\mathrm{I}}_{\text {обр }} ; \\
& \underline{\mathrm{U}}_{\mathrm{c}}=\mathrm{a} \underline{\mathrm{U}}_{\text {пр }}+\underline{\mathrm{a}}^{2} \underline{\mathrm{U}}_{\text {обр }} ; \underline{\mathrm{I}}_{\mathrm{c}}=\mathrm{a} \underline{\mathrm{I}}_{\mathrm{np}}+\mathrm{a}^{2} \underline{I}_{\text {обр}} .
\end{aligned}
$$

The performed transition from differential equations with respect to voltages of a three-phase machine in the axes $\alpha-\beta-0$ to complex equations corresponds to well-known substitution schemes. According to the author, the parameters of the latter can be obtained experimentally or by calculation.

After performing a preliminary calculation of currents, the value of the average for the period of the electromagnetic moment is determined by the formula:

$$
M_{e}=\int_{0}^{T} M(t) d t / T .
$$

As a result, the value of the efficiency of the machine ( $\eta)$ and the power factor $(\cos \varphi)$ is calculated. The considered model allows to perform the energy efficiency analysis of an induction motor at asymmetric non-sinusoidal voltage in the supply network, but requires some refinement, because it considers only static modes similar to the previous one and does not take into account changes in supply voltage.

Based on the analysis of existing mathematical analogues of AM with a short-circuited rotor, we can assume that a single model that allows to assess the energy efficiency of an electric machine operating in poor nutrition, ie takes into account all indicators of electricity quality (IEQ) simultaneously, does not exist. However, there are models that reflect the impact of individual ones.

Such mathematical analogues of the induction motor include the models presented in the works ${ }^{30}$.

30 Копылов И.П. Математическое моделирование электрических машин. Москва : Наука, 2001. 327 с. Математическая модель для исследования трехфазного асинхронного двигателя с короткозамкнутым ротором как объекта регулирования им для прямого процессорного управления. Электротехника. 1998. № 6. С. 51-61; Программное обеспечение для моделирования трехфазного асинхронного двигателя с короткозамкнутым ротором в составе системы управления электроприводами и для бездатчикового измерения регулируемых переменных. Электротехника. 2000. № 1. С. 19-25; Иванов-Смоленский А.В. Электрические машины. В 2-х т. Том 1 : учебник для вузов. 2-е изд., перераб. и доп. Москва : Издательство МЭИ, 2004. 656 с.; Копылов И.П. Щедрин О.П. Расчет на ЦВМ характеристик асинхронных машин. Москва : Энергия. 1973. 212 с. 
In our opinion, to solve this problem, one of the real options may be to create a combined simulation model of an induction motor, where the elements of mathematical analogues described in the above studies would be used as computing units. The main problems are the difficulty of presenting the initial information about the non-sinusoid and asymmetry of the supply voltage, as well as the cumbersomeness and impossibility of their use in the case of non-stationary IEQs. Therefore, the other most flexible and universal option is the direct integration of differential equations describing AM.

\subsection{Development of a dynamic electromagnetic model}

\section{of an induction motor operating in low-quality electricity}

As is known ${ }^{31}$, in cases where the supply voltage is asymmetric, it is necessary to use the method of symmetrical components. The desired parameters, in particular, the function of the stator current of the BP, is found as the geometric sum of the currents of the symmetrical components. The energy parameters of the electromechanical converter are determined based on the current values of the resulting current of the stator and rotor.

The disadvantage of this approach is, firstly, a significant complication of the system of equations describing the object, because when non-sinusoidal power is added, it is necessary to determine the symmetrical components for each harmonic that is taken into account. Then, if there are, for example, 10 harmonic components, for each basic equation that describes the system, you need to make 30 equations.

Second, spectral analysis and decomposition into symmetrical components - procedures that require significant computing resources of the computer. Finding the optimal parameters of the electromechanical system using models based on both symmetric components and spectral analysis, requires a lot of machine time and therefore does not allow a full study of the response surface.

Based on the above, the author ${ }^{32}$ used a system of differential equations in the time domain. In this case, for a comprehensive

31 Бессонов Л.А. Теоретические основы электротехники. Электрические цепи : учебник. 11-е изд., перераб. и доп. Москва : Гардарики, 2007. $701 \mathrm{c.}$

32 Kuznetsova Ye., Kuznetsov V., Tryputen M., Kuznetsova A., Tryputen M., Babyak M. Development and Verification of Dynamic Electromagnetic Model of Asynchronous Motor Operating in Terms of Poor-Quality Electric Power. Proceedings of the International Conference on Modern Electrical and Energy Systems, MEES 2019. pp. 350-353. DOI: 10.1109/MEES.2019.8896598. 
accounting of supply voltage parameters, it is advisable to use either space-time complexes (SPC), or generalized vectors of quantities that change periodically over time and are recorded relative to their instantaneous values.

The SPC for any $\underline{Y}$ is calculated as follows ${ }^{33}$ :

$$
\underline{Y}=\frac{2}{3}\left(Y_{A}+\alpha Y_{B}+\alpha^{2} Y_{C}\right),
$$

where $Y_{A}, Y_{B}, Y_{C}$ - phase values of the considered value at a given moment of time, and the latter correspond to the projection of the specified complex on the phase axis.

The Park-Gorev equations written in relation to the SPC, which are the basis of the known AM models, have the form::

$$
\begin{aligned}
& \underline{U}_{1}=\underline{I}_{1} R_{1}+\underline{I}_{0} R_{0}+\frac{d \underline{\Psi}_{1}}{d t} ; \\
& 0=\underline{I}_{2} R_{2}+\underline{I}_{0} R_{0}+\frac{d \underline{\Psi}_{2}}{d t}-j \omega_{r} \underline{\Psi}_{2},
\end{aligned}
$$

where $\underline{U}_{1}$ - SPC stator voltage; $\underline{I}_{1}, \underline{I}_{2}, \underline{I}_{0}$ - SPCs stator and roror currents, and magnetizing current; $\underline{\Psi}_{1}, \underline{\Psi}_{2}$ - SPCs stator and rotor flux couplings; $\omega_{r}$ - angular velocity of rotation of $\mathrm{AM} ; R_{1}, R_{2}$ - active stator and rotor resistances.

It should be borne in mind that the dynamic and energy performance of induction motors is significantly affected by the saturation of the magnetic circuit. The saturation phenomenon is due to the limiting orientation of the magnetic dipoles in the material of the latter, and, thus, the cessation of the growth of the magnetic flux with increasing magnetizing current, as shown in fig. 3.

There are different methods of accounting for this effect ${ }^{34}$. The best combination of accuracy and simplicity of calculations gives the use of the dependence of the main mutual inductance on the magnitude of the

33 Иванов-Смоленский А.В. Электрические машины. В 2-х т. Том 1 : учебник для вузов. 2-е изд., перераб. и доп. Москва : Издательство МЭИ, 2004. 656 с.

34 Иванов-Смоленский А.В. Электрические машины. В 2-х т. Том 1: Учебник для вузов. 2-е изд., перераб. и доп. Москва: Издательство МЭИ, 2004. 656 c.; Kuznetsova Ye., Kuznetsov V., Tryputen M., Kuznetsova A., Tryputen M., Babyak M. Development and Verification of Dynamic Electromagnetic Model of Asynchronous Motor Operating in Terms of Poor-Quality Electric Power. Proceedings of the International Conference on Modern Electrical and Energy Systems, MEES 2019. pp. 350-353. DOI: 10.1109/MEES.2019.8896598. 
magnetizing current $\mathrm{L}_{12}=\mathrm{f}\left(\mathrm{I}_{0}\right)$. For example, in $^{35}$ the dependence of the inductance on the magnetizing current for induction motors of general industrial design (fig. 4).

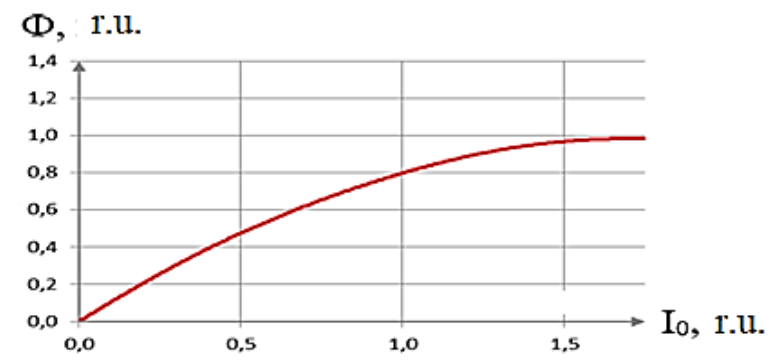

Fig. 3. Dependence of the main magnetic flux on the magnetizing current

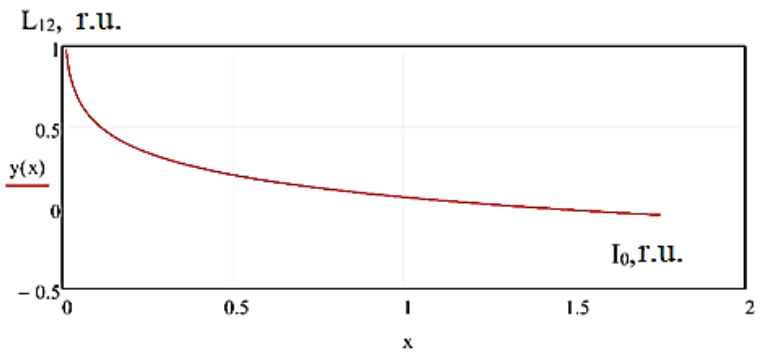

Fig. 4. Dependence of the main inductance on the magnetizing current

This dependence can be described by polynomial functions of even degrees. The value of the inductance of the magnetization branch without taking into account the effect of saturation is given in the reference literature $^{36}$, or can be approximately determined by the results of the idling experiment ${ }^{37}$. Determining the coefficients of the polynomial

35 Оценка нелинейности индуктивности катушки со сталью энергетическим методом / В.А. Огарь. Вестник КрГПУ. 2004. Вып. 2/2004 (25). С.78-84.

36 Вешеневский С.Н. Характеристики двигателей в электроприводе. Изд. 6-е, исправленное. Москва : Энергия, 1977. 431с.

37 ГОСТ 7217-87 «Машины электрические вращающиеся. Двигатели асинхронные. Методы испытаний» 
dependence of the inductance on the magnitude of the magnetizing current is an independent task. The equation from $^{38}$ was used for modeling by the author.

Thus, in the equations to determine the flow coupling it is necessary to write:

$$
\begin{gathered}
\underline{\Psi}_{1}=\underline{\mathrm{I}}_{1} \cdot \mathrm{L}_{1}+\mathrm{L}_{12}\left(\mathrm{I}_{0}\right) \cdot \underline{\mathrm{I}}_{2} \\
\underline{\Psi}_{2}=\underline{\mathrm{I}}_{2} \cdot \mathrm{L}_{2}+\mathrm{L}_{12}\left(\mathrm{I}_{0}\right) \cdot \underline{\mathrm{I}}_{1}
\end{gathered}
$$

The block diagram of the modeling object, reflecting equations (2.11) and (2.12), taking into account (2.13) and (2.14), is presented in fig. 5.

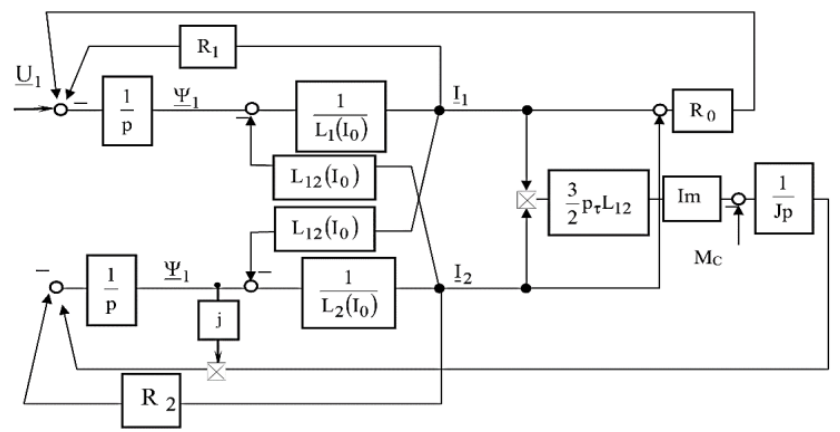

\section{Fig. 5. Block diagram of an induction motor as a modeling object}

All parameters in the electromechanical system - the voltage on the magnetization branch, the stator and rotor currents are calculated taking into account the saturation in the steel. Since the analysis of the SPC of all signals in the time domain, it allows to take into account the instantaneous values of currents and voltages, there is no need for spectral analysis and compilation of equations for each harmonic. In addition, such equations are actually a condensed form of recording all three phases, and this makes it possible to take into account the asymmetry of the supply voltage. The already mentioned system is, in fact, a universal model that allows you to analyze processes in both steady and transient modes (start, run, load change).

The analytical solution of the system of equations (2.11), (2.12) is difficult and is associated with a number of essential assumptions ${ }^{39}$. In such

${ }^{38}$ Kerkman O, Russel J. Steady-State and Transient Analyses of an Induction Machine with Saturation of the Magnetizing Branch. IEEE Transactions on Industry Applications. 1985. Vol. 21. P. 226-234. 
cases, resort to known numerical methods, namely: Euler's method, modified Euler's method and Runge-Kutta method of order $\mathrm{IV}^{40}$, the essence of which is to represent infinitesimal increments of the desired function $\mathrm{f}(\mathrm{t})$ by some finite values and notation of equations in the form of Cauchy ${ }^{41}$. The simplest of the numerical methods is the Euler method, which is also called the broken method or the tangent method. In computational practice, this method is rarely used due to low accuracy. But on his example it is convenient to explain some concepts and ideas of construction and research of numerical methods of solving the Cauchy problem ${ }^{42}$ :

$$
\frac{\mathrm{df}(\mathrm{t})}{\mathrm{dt}}=\frac{\mathrm{y}_{\mathrm{k}}-\mathrm{y}_{\mathrm{k}-1}}{\mathrm{~h}}
$$

where $\mathrm{h}-$ is the integration step; $\mathrm{y}_{\mathrm{k}}$ and $\mathrm{y}_{\mathrm{k}-1}$ - are the integrated value on the $\mathrm{k}^{\text {th }}$ and (k-1) ${ }^{\text {th }}$ steps. As a result, the desired function takes the form:

$$
\mathrm{y}_{\mathrm{k}}=\mathrm{y}_{\mathrm{k}-1}+\frac{\mathrm{df}(\mathrm{t})}{\mathrm{dt}} \mathrm{h} \text {, }
$$

using which according to its initial values, step by step determine the array of the transition process.

Formula (2.16) is called the Euler formula, and the numerical method for solving the Cauchy problem defined by formula (2.16) is called the Euler method.

A modified Euler method can be obtained by applying the quadrature formula

$$
\Delta y_{i}=\int_{x_{i}}^{x_{i+1}} f(x, y(x)) \cdot d x .
$$

of a trapezoid to the approximate calculation of integrals:

$$
\Delta y_{i}=\frac{h_{i}}{2}\left(f\left(x_{i}, y\left(x_{i}\right)\right)+f\left(x_{i}+h_{i}, y\left(x_{i}+h_{i}\right)\right)+O\left(h_{i}^{3}\right) .\right.
$$

39 Иванов-Смоленский А.В. Электрические машины. В 2-х т. Том 1: Учебник для вузов. 2-е изд., перераб. и доп. Москва : Издательство МЭИ, 2004. 656 с.

40 Бойко Л.Т. Основи чисельних методів. Навчальний посібник. Дніпропетровськ : Видавництво ДНУ. 2009. 244 с.

${ }^{41}$ Башарин А.В. Постников Ю.В. Примеры расчета автоматизированного электропривода на ЭВМ : учебное пособие для вузов. 3-е изд. Ленинград: Энергоатомиздат, Ленинградское отд-ние. 1990. 210 с.

42 Бойко Л.Т. Основи чисельних методів. Навчальний посібник. Дніпропетровськ : Видавництво ДНУ. 2009. 244 с. 
Rejecting the error in (2.17) $O\left(h_{i}^{3}\right)$, we arrive at an approximate equation with respect to the desired value $y_{i+1}$ :

$$
y_{i+1}=y_{i}+\frac{h_{i}}{2}\left(f\left(x_{i}, y_{i}\right)+f\left(x_{i+1}, y_{i+1}\right)\right) \text {. }
$$

Equation (2.18) is an example of an implicit one-step method because it is not solved with respect to $y_{i+1}$. But, if we use Euler's formula, then within the accepted error $O\left(h_{i}^{3}\right)$ the nonlinear equation (2.18) can be linearized. This is done as follows. In the right part of formula (2.17) we replace the value of $y\left(x_{i}+h_{i}\right)$ with such a development:

$$
y\left(x_{i}+h_{i}\right)=y\left(x_{i}\right)+h_{i} \cdot f\left(x_{i}, y\left(x_{i}\right)\right)+O\left(h_{i}^{2}\right)=y^{*}\left(x_{i+1}\right)+O\left(h_{i}^{2}\right),
$$

where marked

$$
y^{*}\left(x_{i+1}\right)=y\left(x_{i}\right)+h_{i} \cdot f\left(x_{i}, y\left(x_{i}\right)\right) .
$$

Then

$$
f\left(x_{i+1}, y\left(x_{i}+h_{i}\right)\right)=f\left(x_{i+1}, y^{*}\left(x_{i+1}\right)+O\left(h_{i}^{2}\right)\right)=f\left(x_{i+1}, y^{*}\left(x_{i+1}\right)\right)+O\left(h_{i}^{2}\right) .
$$

Substituting (2.19) to (2.17), we arrive at two calculation formulas:

$$
\left\{\begin{array}{c}
y_{i+1}^{*}=y_{i}+h_{i} \cdot f\left(x_{i}, y_{i}\right) \\
y_{i+1}=y_{i}+\frac{h_{i}}{2}\left(f\left(x_{i}, y_{i}\right)+f\left(x_{i+1}, y_{i+1}^{*}\right)\right)
\end{array}\right.
$$

The local error of formulas (2.20) is $O\left(h_{i}^{3}\right)$, ie, an order of magnitude smaller than in Euler's formula. Calculation formulas (2.20) are a modification of Euler's formula.

As is known ${ }^{43}$, the solution of the system of equations can be carried out using the Runge-Kutta method of the IV order, which has the highest accuracy of calculation.

Suppose we need to find a solution to the Cauchy problem (2.11), (2.12). For this purpose on the set segment $[a, b]$. we fix points $x_{i}, i=\overline{0, n}$ with a variable step $h_{i}=x_{i+1}-x_{i}, i=\overline{0, n-1}$. We will look for the value of the function $y(x)$ at these points, using the calculation formula $y\left(x_{i+1}\right)=y\left(x_{i}\right)+\Delta y_{i}, i=\overline{0, n-1}$. Consider a separate segment

43 Бойко Л.Т. Основи чисельних методів. Навчальний посібник. Дніпропетровськ : Видавництво ДНУ. 2009. 244 с. 
$\left[x_{i}, x_{i+1}\right]$, assuming that the value of $y\left(x_{i}\right)$ is known, and look for an increment $\Delta y_{i}=\int_{x_{i}}^{x_{i+1}} f(x, y(x)) \cdot d x$.

For an approximate calculation of the increment of the $\Delta y_{i}=\int_{x_{i}}^{x_{i+1}} f(x, y(x)) \cdot d x$. function, let's introduce three sets of parameters for consideration:

$$
\begin{gathered}
\alpha_{1}, \alpha_{2}, \ldots, \alpha_{q} ; \\
\beta_{10} ; \\
\beta_{20}, \beta_{21} ; \\
\ldots ; \\
\beta_{q 0}, \beta_{q 1}, \ldots, \beta_{q, q-1} ; \\
A_{0}, A_{1}, \ldots, A_{q} .
\end{gathered}
$$

Using the parameters (2.21), (2.22) make the values:

$$
\left\{\begin{array}{c}
\phi_{0}=h_{1} \cdot f\left(x_{i}, y_{i}\right), \\
\phi_{1}=h_{i} \cdot f\left(x_{i}+\alpha_{1} \cdot h_{i}, y_{i}+\beta_{10} \cdot \phi_{0}\right), \\
\phi_{2}=h_{i} \cdot f\left(x_{i}+\alpha_{2} \cdot h_{i}, y_{i}+\beta_{20} \cdot \phi_{0}+\beta_{21} \cdot \phi_{1}\right), \\
\ldots, \\
\phi_{q}=h_{i} \cdot f\left(x_{i}+\alpha_{q} \cdot h_{i}, y_{i}+\sum_{m=0}^{q-1} \beta_{q m} \cdot \phi_{m}\right) .
\end{array}\right.
$$

Now we write a linear combination of quantities (2.24) with coefficients (2.23):

$$
\sum_{j=0}^{q} A_{j} \cdot \phi_{j}
$$

The linear combination (2.25) will be analogous to the quadrature sum for calculating the integral $\Delta y_{i}=\int_{x_{i}}^{x_{i+1}} f(x, y(x)) \cdot d x$, that is, the increase in $\Delta y_{i}$ function. Parameters (2.21), (2.22), (2.23) are chosen so that (2.25) approximates the increment of the $\Delta y_{i}$ function as accurately as possible. To do this, the approximation error, ie the value of 
$r_{q}\left(h_{i}\right)=\Delta y_{i}-\sum_{j=0}^{q} A_{j} \cdot \phi_{j}$, as a function of step $h_{i}$, we develop in the Taylor series in the vicinity of the value of $h_{i}=0$ :

$$
r_{q}\left(h_{i}\right)=r_{q}(0)+\frac{h_{i}}{1 !} r_{q}^{\prime}(0)+\frac{h_{i}^{2}}{2 !} r_{q}^{\prime \prime}(0)+\ldots+\frac{h_{i}^{k}}{k !} r_{q}^{(k)}(0)+\frac{h_{i}^{k+1}}{(k+1) !} r_{q}^{(k+1)}\left(\theta h_{i}\right), 0 \leq \theta \leq 1 .
$$

If the parameters $(2.21),(2.22),(2.23)$ can be chosen so that the conditions for the development of (2.26) are met

$$
\left\{\begin{array}{c}
r_{q}(0)=0, \\
r_{q}^{\prime}(0)=0, \\
\cdots, \\
r_{q}^{(k)}(0)=0, \\
r_{q}^{(k+1)}(0) \neq 0,
\end{array}\right.
$$

then the error $r_{q}\left(h_{i}\right)$ will be the same order of magnitude as $h_{i}^{k+1}$, ie

$$
r_{q}\left(h_{i}\right)=\frac{h_{i}^{k+1} 9}{(k+1) !} r_{q}^{(k+1)}\left(\theta h_{i}\right), 0 \leq \theta \leq 1 .
$$

The number $\mathrm{k}$ will be called the order (degree) of accuracy of the Runge-Kutta method. The local error is determined by formula (2.28), and the calculation formula takes the form:

$$
y_{i+1}=y_{i}+\sum_{j=0}^{q} A_{j} \cdot \phi_{j} .
$$

Fixing the number q, we have a specific variant of the Runge-Kutta method.

In the case of $q=3$, the system of constraints on the choice of the parameters $(\alpha),(\beta)$, and $(A)$ of the computational rules of the RungeKutta type of the fourth order of accuracy can be reduced to

$$
\begin{gathered}
A_{0}+A_{1}+A_{2}+A_{3}=1, A_{1} \alpha_{1}+A_{2} \alpha_{2}+A_{3} \alpha_{3}=\frac{1}{2}, \\
A_{1} \alpha_{1}^{2}+A_{2} \alpha_{2}^{2}+A_{3} \alpha_{2}^{3}=\frac{1}{3}, A_{1} \alpha_{1}^{3}+A_{2} \alpha_{2}^{3}+A_{3} \alpha_{3}^{3}=\frac{1}{4}, \\
A_{2} \beta_{21} \alpha_{1}+A_{3} \beta_{31} \alpha_{1}+A_{3} \beta_{32} \alpha_{2}=\frac{1}{6}, \\
A_{2} \beta_{21} \alpha_{2} \alpha_{1}+A_{3} \beta_{31} \alpha_{3} \alpha_{1}+A_{3} \beta_{32} \alpha_{3} \alpha_{2}=\frac{1}{8},
\end{gathered}
$$




$$
\begin{gathered}
A_{2} \beta_{21} \alpha_{1}^{2}+A_{3} \beta_{31} \alpha_{1}^{2}+A_{3} \beta_{32} \alpha_{2}^{2}=\frac{1}{12}, \\
A_{3} \beta_{32} \beta_{21} \alpha_{1}=\frac{1}{24},
\end{gathered}
$$

The variables of the state of the object being modeled in this case are the speed of the induction motor, as well as the space-time complexes of the flux couplings of the stator and rotor. The electromagnetic moment of the AM relative to space-time complexes is expressed as follows:

$$
\mathrm{M}=\frac{3}{2} \mathrm{p}_{\tau} \mathrm{L}_{12} \operatorname{Im}\left(\underline{I}_{1}^{*} \underline{I}_{2}\right),
$$

Finally, the desired system must be supplemented by the basic equation of dynamics:

$$
\mathbf{M}-\mathbf{M}_{\mathrm{c}}=\mathbf{J} \frac{\mathrm{d} \omega_{\mathrm{r}}}{\mathrm{dt}},
$$

where $\mathrm{M}_{\mathrm{c}}$ - static moment; $\mathrm{J}$ - the moment of inertia of the mechanical part of the drive; $p_{\tau}-$ number of pole pairs.

Thus, in this section of the author's analysis of existing models of induction motors, which are described in the literature and developed a simulation mathematical analogue of AM, which allows to determine the energy performance of the latter with an arbitrary change in time quality of electricity. The author improved the model by adding a unit that takes into account the saturation of the magnetic circuit, by using the dependence of the main mutual inductance on the magnitude of the magnetizing current.

\section{Examples of calculations on the developed model of the induction motor working in the conditions of low-quality electric power by means of various methods of numerical integration. search for optimal values of the harmonic spectrum of the input voltage according to a given criterion}

\subsection{Block diagram of the developed combined simulation model of an induction motor}

The software implementation of the proposed model of BP, operating under conditions of low-quality power supply, developed in the software product Mathcad 14 is presented in addition A. It is tested by describing the process of starting, sketching the load and the set mode of the motor 
type MTKH 112-6 with a capacity of $5.3 \mathrm{~kW}$, characterized by the following values: $\mathrm{U}_{1 \mathrm{n}}=380 \mathrm{~V}, \mathrm{n}_{\mathrm{n}}=875 \mathrm{rpm}, \mathrm{J}=0,08 \mathrm{~kg} \cdot \mathrm{m}^{2}, \mathrm{R}_{1}=1,61 \Omega$, $\mathrm{R}_{2}=2,19 \Omega, \mathrm{R}_{0}=6,2 \Omega, \mathrm{L}_{1 \sigma}=0,00362 \mathrm{H}, \mathrm{L}_{2 \sigma}=0,00365 \mathrm{H}, \mathrm{L}_{12}=0,294 \mathrm{H}^{44}$. As a power supply, first an ideal three-phase voltage was used, and then an asymmetric non-sinusoidal voltage corresponding to the actually fixed one, the indicators of which are presented in table 1.

Hodographs of the SPC of these voltages are presented in fig. 6, show that asymmetric, non-sinusoidal power supply determines its complex shape.

\section{Supply voltage quality indicators}

\begin{tabular}{|c|c|c|c|c|c|c|c|c|c|c|c|}
\hline \multicolumn{1}{|c|}{$\begin{array}{c}\text { Phase voltage } \\
\text { deviation, \% }\end{array}$} & \multicolumn{10}{|c|}{ Coefficients of harmonic components, \% } \\
\hline A & B & C & 2 & 3 & 4 & 5 & 6 & 7 & 8 & 9 & 10 \\
\hline 11,2 & 18,8 & 1,0 & 5,8 & 0,83 & 1,69 & 0,03 & 2,78 & 0,03 & 0,08 & 0,23 & 0,04 \\
\hline
\end{tabular}

a)

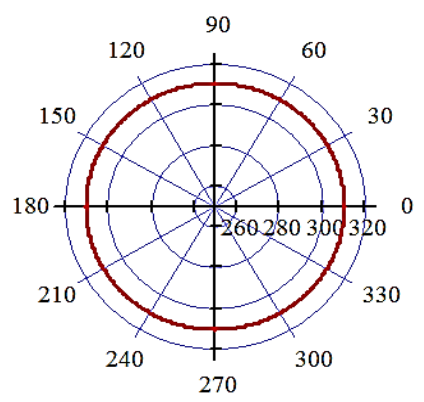

б)

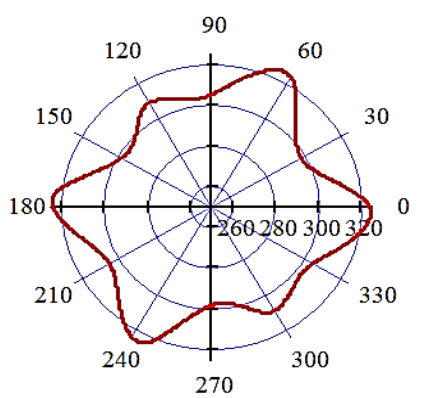

Fig. 6. Hodograph of the space-time supply voltage complex: a) ideal; b) asymmetric non-sinusoidal

Fig. 7 shows the obtained graphs of transients (start, sketch of the rated load) at ideal and curved voltage.

44 Kuznetsova Ye., Kuznetsov V., Tryputen M., Kuznetsova A., Tryputen M., Babyak M. Development and Verification of Dynamic Electromagnetic Model of Asynchronous Motor Operating in Terms of Poor-Quality Electric Power. Proceedings of the International Conference on Modern Electrical and Energy Systems, MEES 2019. pp. 350-353. DOI: 10.1109/MEES.2019.8896598. 


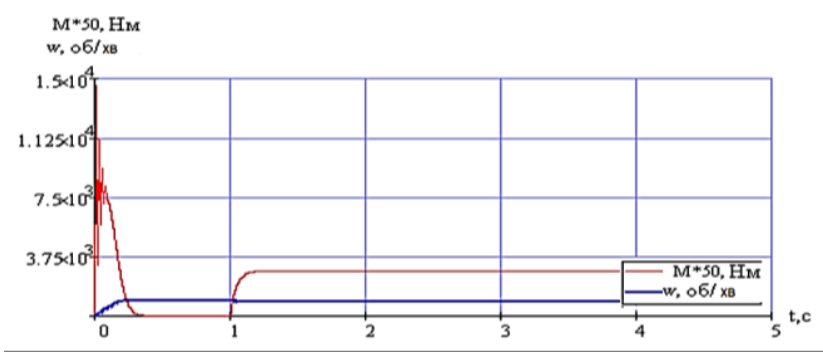

a)

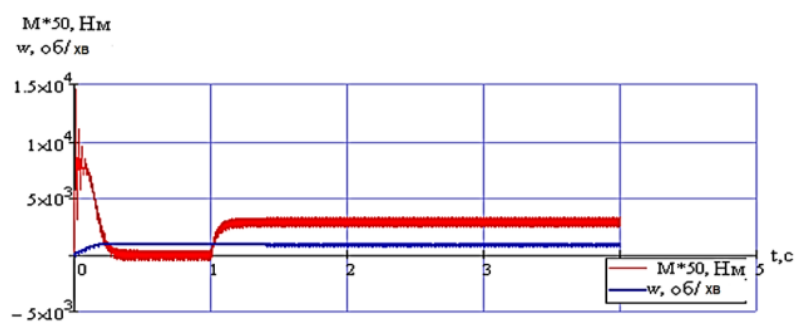

b)

Fig. 7. The moment and speed of the BP during start-up and nakida load at ideal:

(a) and asymmetric non-sinusoidal (b) voltage

The hodograph of the torque of the induction motor during one revolution has the form shown in fig. 8 .

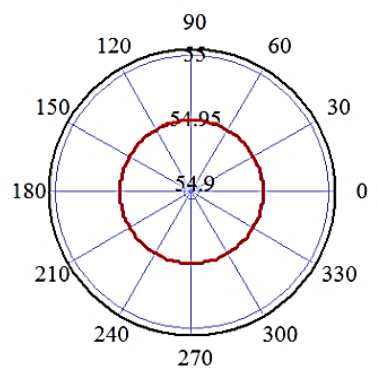

a)

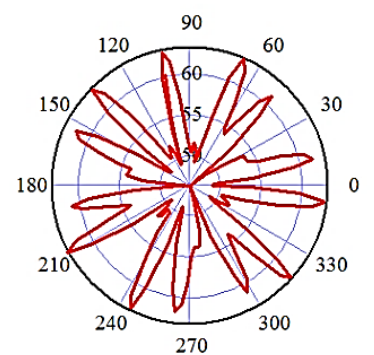

б)

Fig. 8. Hodograph of the moment of BP with ideal:

(a) and poor (b) power supply in the set mode 
Here, the resulting stator and rotor currents are used to calculate the energy parameters. In this case, the electrical losses are calculated by the known expressions of Joule - Lenz $^{45}$. Obtained in this example, the instantaneous values of these currents in the set mode have the form shown in fig. 9.

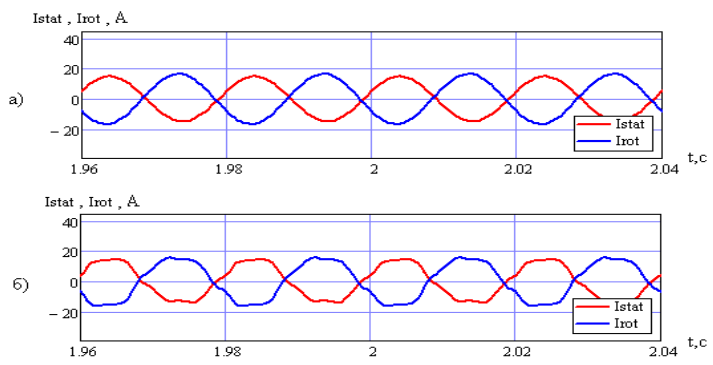

Fig. 9. Stator and rotor currents at ideal:

(a) and poor (b) power supply in the set mode

As is known, in motors with a nominal voltage of $0.4 \mathrm{kV}$, approximately half of all losses are losses in steel. In high-voltage motors (for example, $6 \mathrm{kV}$ ) the share of losses in steel reaches $75 \%$ due to the small share of electric.

Losses in the steel of an induction motor are, as a rule, according to empirical formulas ${ }^{46}$ which include voltage, incl. harmonic components, frequency to some extent, etc. There is a known inaccuracy of this approach, especially in the case of distorted power supply or voltage other than the nominal. Therefore, the model pre-calculates the magnetizing current:

$$
\underline{I}_{0}=\underline{I}_{1}+\underline{I}_{2},
$$

and only then the specified losses are calculated:

$$
P_{C}=\left|\underline{I}_{0}\right|^{2} R_{0},
$$

where $R_{0}$ - active resistance of the magnetization branch.

The block diagram of the developed model of the induction motor is presented in fig. 10. It allows to estimate the considered energy parameters of the induction motor in any mode, at any form of supply voltage.

${ }^{45}$ Иванов-Смоленский А.В. Электрические машины. В 2-х т. Том 1 : Учебник для вузов. 2-е изд., перераб. и доп. Москва : Издательство МЭИ, 2004. 656 с.

${ }^{46}$ Иванов-Смоленский А.В. Электрические машины. В 2-х т. Том 1 : учебник для вузов. 2-е изд., перераб. и доп. Москва : Издательство МЭИ, 2004. 656 с. 


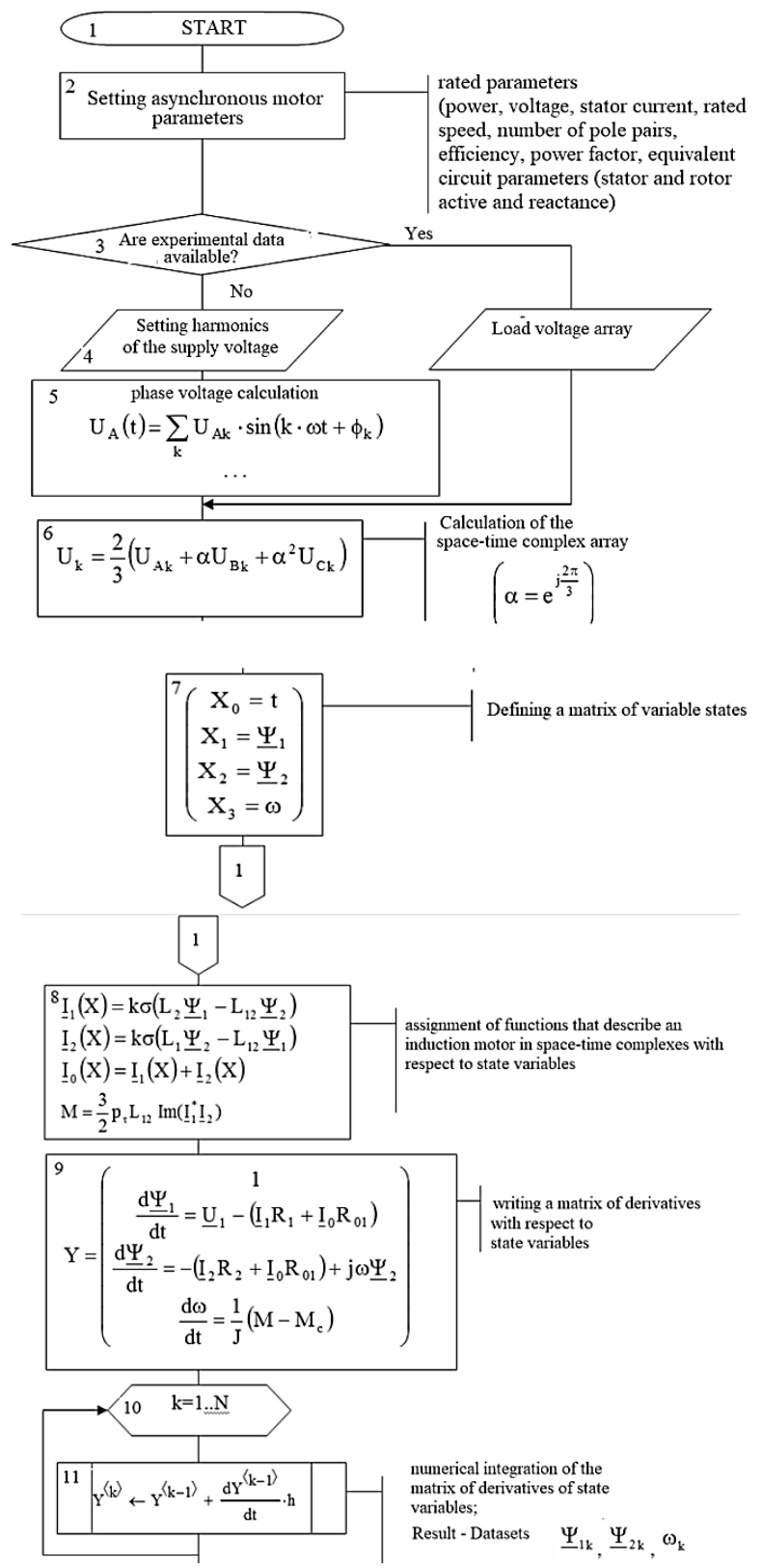




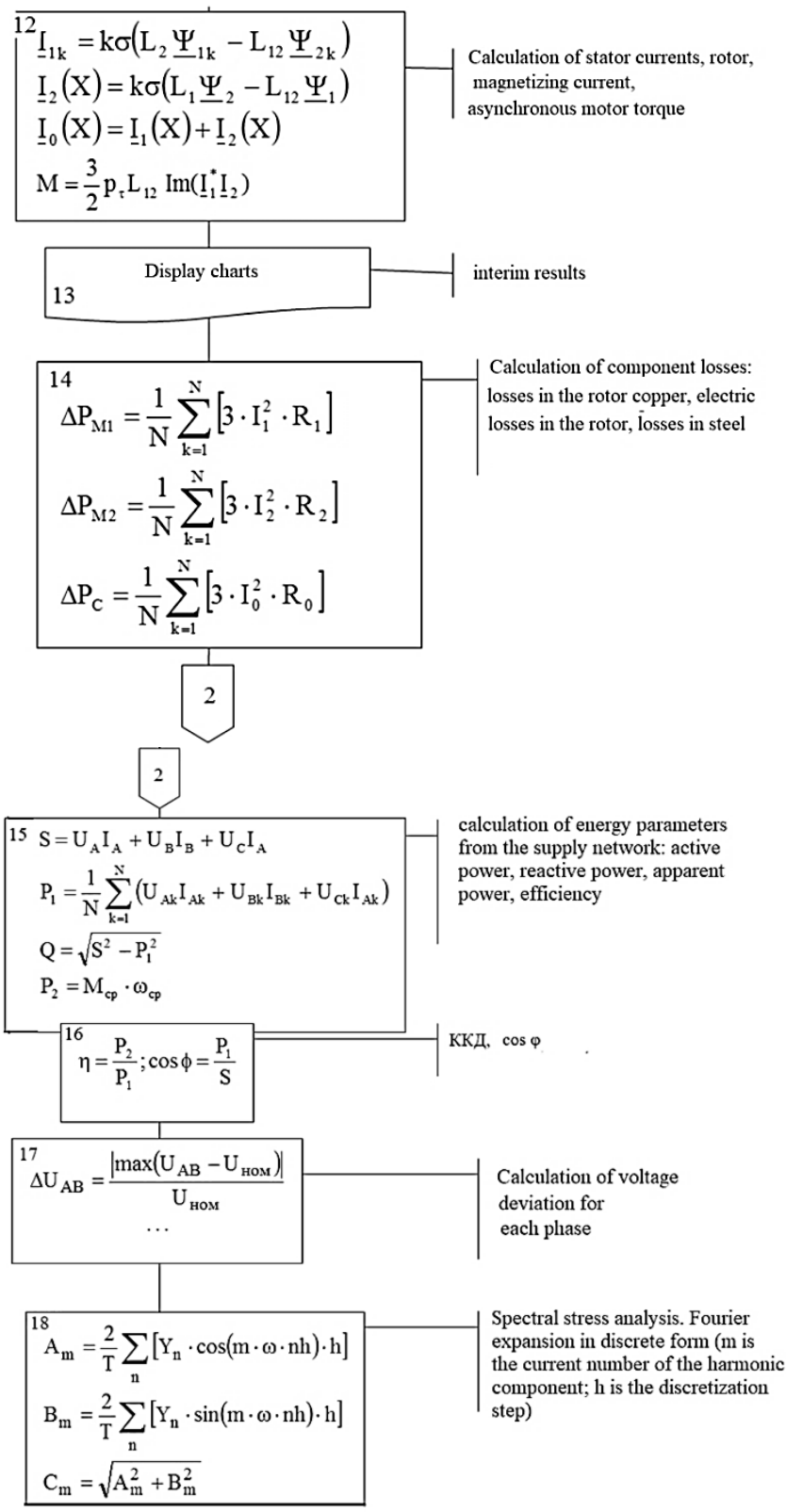




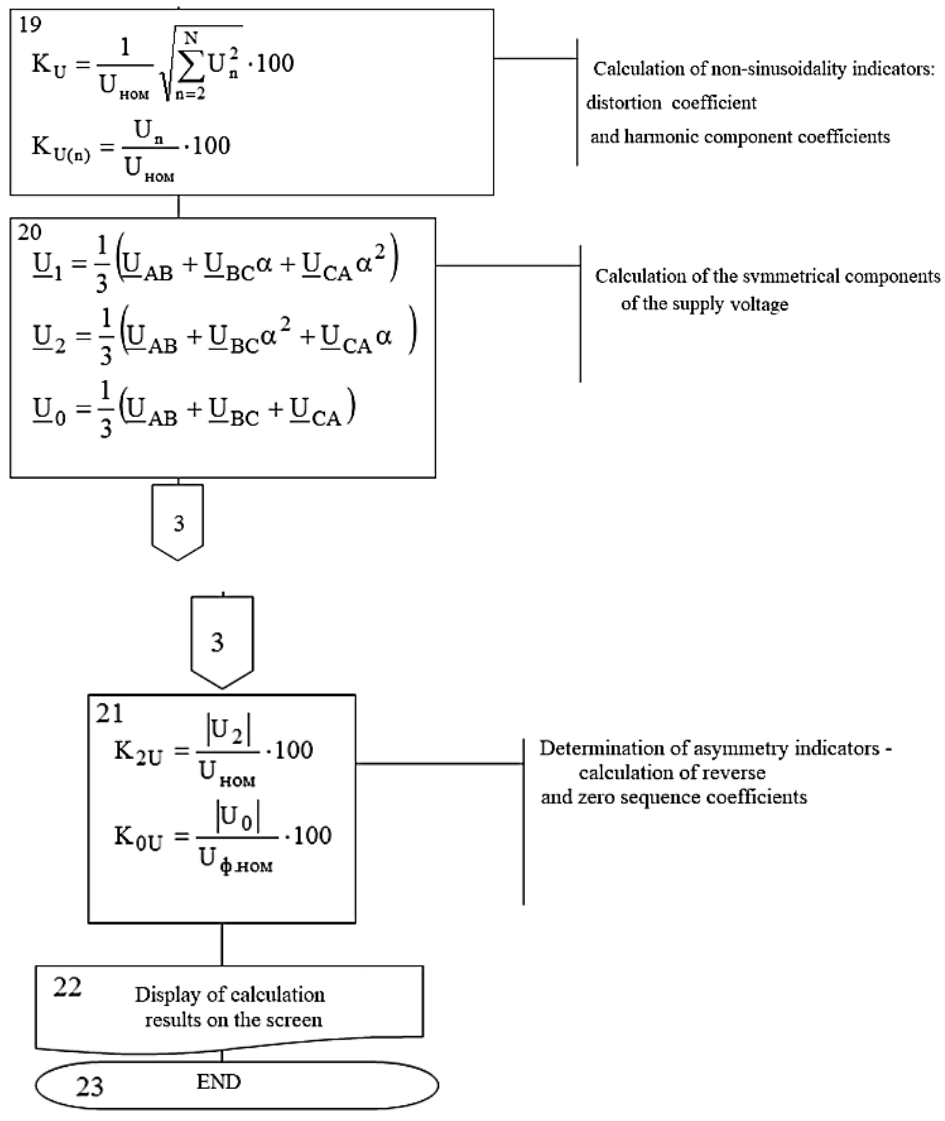

Fig. 10. Block diagram of the developed combined simulation model of AM

In block 11 fig. 10 implemented an algorithm for solving a system of first-order differential equations describing the operation of an induction motor by the Euler method. A fragment of the software implementation of this block is presented in fig. 11 . 


\section{Transient Modeling}

Simulation time

Simtime $\equiv 4$

Discretization step

$\mathrm{h} \equiv 0.00001$

Number of points

$$
\mathrm{N}:=\frac{\text { Simtime }}{\mathrm{h}}=4 \times 10^{5}
$$

Functions Describing an Asynchronous Motor

$$
\begin{aligned}
& \mathrm{U}_{1}(\mathrm{X}):=\mathrm{U}\left(\mathrm{x}_{0}\right) \quad \text { Voltage functions } \\
& \mathrm{I}_{1}(\mathrm{X}):=\mathrm{k} \sigma \cdot\left(\mathrm{L}_{2} \cdot \mathrm{X}_{1}-\mathrm{L}_{12} \cdot \mathrm{X}_{2}\right) \quad \text { Functions of currents from state variables } \\
& \mathrm{I}_{2}(\mathrm{X}):=\mathrm{k} \sigma \cdot\left(\mathrm{L}_{1} \cdot \mathrm{X}_{2}-\mathrm{L}_{12} \cdot \mathrm{X}_{1}\right) \\
& \mathrm{I}_{0}(\mathrm{X}):=\mathrm{I}_{1}(\mathrm{X})+\mathrm{I}_{2}(\mathrm{X}) \\
& \mathrm{M}(\mathrm{X}):=\frac{3}{2} \cdot \mathrm{p}_{\tau} \cdot \operatorname{Im}\left(\overline{\mathrm{X}_{1}} \cdot \mathrm{I}_{1}(\mathrm{X})\right) \\
& \begin{array}{l}
\text { Asynchronous motor } \\
\text { moment }
\end{array} \\
& t_{1}:=1 \\
& \mathrm{M}_{\mathrm{c}}:=1 \cdot \mathrm{M}_{\text {nom }}=57.841
\end{aligned}
$$

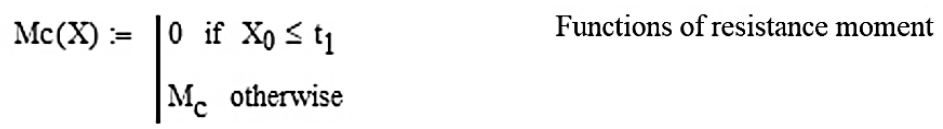

State variable matrix

$$
\operatorname{STATE}(X):=\left(\begin{array}{c}
1 \\
U_{1}(X)-I_{1}(X) \cdot R_{1}-I_{0}(X) \cdot R_{0} \\
-I_{2}(X) \cdot R_{2}-I_{0}(X) \cdot R_{0}+j \cdot p_{\tau} \cdot X_{3} \cdot X_{2} \\
\frac{M(X)-M c(X)}{J m}
\end{array}\right)
$$

Simulation cycle

TRANS : $=\mid \begin{aligned} & y^{\langle 0\rangle} \leftarrow X n \\ & \text { for } k \in 1 \ldots N \\ & y^{\langle k\rangle} \leftarrow y^{\langle k-1\rangle}+\operatorname{STATE}\left(y^{\langle k-1\rangle}\right) \cdot h \\ & y^{T}\end{aligned}$

$$
\mathrm{k}:=0 . \mathrm{N}
$$$$
\mathrm{t}:=\operatorname{TRANS}^{\langle 0\rangle} \quad \Psi 1:=\operatorname{TRANS}^{\langle 1\rangle} \quad \Psi \cdot=\operatorname{TRANS}^{\langle 2\rangle} \quad \text { Speed }:=\operatorname{TRANS}^{\langle 3\rangle}
$$$$
\mathrm{I}_{\mathrm{L}_{\mathrm{k}}}:=\left(\mathrm{L}_{2} \cdot \Psi 1_{\mathrm{k}}-\mathrm{L}_{12} \cdot \Psi 2_{\mathrm{k}}\right) \cdot \mathrm{k} \sigma \quad \mathrm{I}_{2_{\mathrm{k}}}:=\left(\mathrm{L}_{1} \cdot \Psi 2_{\mathrm{k}}-\mathrm{L}_{12} \cdot \Psi 1_{\mathrm{k}}\right) \cdot \mathrm{k} \sigma \quad \mathrm{I}_{\mathrm{A}_{\mathrm{k}}}:=\mathrm{I}_{1_{\mathrm{k}}}+\mathrm{I}_{2_{\mathrm{k}}}
$$

Fig. 11. A fragment of the software implementation of solving a system of differential equations by Euler's method 
Here is block 11 fig. 10 with the implementation of the algorithm for solving a system of first-order differential equations describing the operation of an induction motor by a modified Euler method. A fragment of the software implementation of this block is presented in fig. 12 .

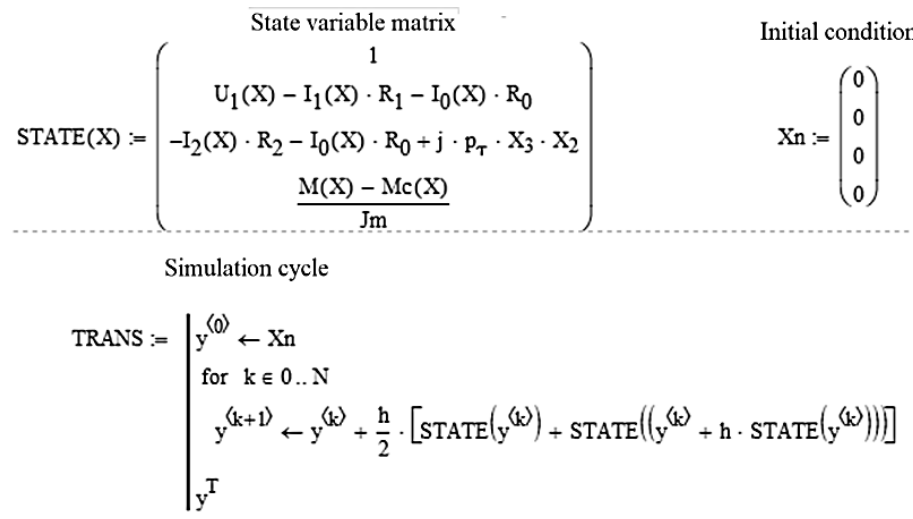

Fig. 12. Fragment of the software implementation of the solution of the system of differential equations by the modified Euler method

State variable matrix

$$
\begin{aligned}
\operatorname{STATE}(X):=\left(\begin{array}{c}
1 \\
U_{1}(X)-I_{1}(X) \cdot R_{1}-I_{0}(X) \cdot R_{0} \\
-I_{2}(X) \cdot R_{2}-I_{0}(X) \cdot R_{0}+j \cdot p_{\tau} \cdot X_{3} \cdot X_{2} \\
\frac{M(X)-M c(X)}{J m}
\end{array}\right) \\
\quad a:=0 \quad b:=10
\end{aligned}
$$

Simulation cycle

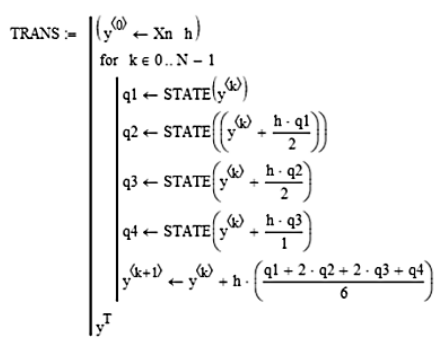

Fig. 13. Fragment of the software implementation of the solution of the system of differential equations by the method of Runge-Kutta IV order 
Here is block 11 fig. 7 with the implementation of the algorithm for solving the system of first-order differential equations describing the operation of an induction motor by the Runge-Kutta method of the IV order. A fragment of the software implementation of this block is presented in fig. 13.

Table 2 shows the results of a drawing of energy indicators for an asynchronous motor type MTKH 112-6 with a need for $5.3 \mathrm{~kW}$ with unbalanced non-sinusoidal energization, with the help of the numerical methods of the Integrated method, the method of the Euler method of method. For an hour of modeling for the next program, Crock Integrated adding $\mathrm{h}=1 \cdot 10^{-5}$. The number of sampled points accumulated $\mathrm{N}=4 \cdot 10^{5}$.

Table 2

\section{Energy indicators of asynchronous dvigun type MTKH 112-6 power 5.3kW}

\begin{tabular}{|c|c|c|c|c|}
\hline \multirow{2}{*}{ Indicators } & \multirow{2}{*}{$\begin{array}{c}\text { Units of } \\
\text { measurement }\end{array}$} & $\begin{array}{c}|c| \\
\text { Euler's } \\
\text { method }\end{array}$ & $\begin{array}{c}\text { Mower supply is non-sinusoidal, } \\
\text { asymetric } \\
\text { Euler } \\
\text { method }\end{array}$ & $\begin{array}{c}\text { Runge - } \\
\text { Kutta } \\
\text { method of } \\
\text { the IV } \\
\text { order }\end{array}$ \\
\cline { 3 - 5 } & Watt & 827,744 & 834,715 & 848,379 \\
\hline $\begin{array}{c}\text { Electrical losses in } \\
\text { the stator }\end{array}$ & Watt & 874,06 & 884,35 & 899,489 \\
\hline $\begin{array}{c}\text { Electrical losses in } \\
\text { the rotor }\end{array}$ & Watt & 83,092 & 83,424 & 83,317 \\
\hline $\begin{array}{c}\text { Electrical losses in } \\
\text { steel }\end{array}$ & Watt & $1,7849 \cdot 10^{3}$ & $1,8025 \cdot 10^{3}$ & $1,8312 \cdot 10^{3}$ \\
\hline Total losses & $5,225 \cdot 10^{3}$ & $5,331 \cdot 10^{3}$ & $5,331 \cdot 10^{3}$ \\
\hline $\begin{array}{c}\text { Power on the } \\
\text { motor shaft }\end{array}$ & Watt & 0,745 & 0,747 & 0,744 \\
\hline Efficiency & $\%$ & 0.804 & 0,806 & 0,804 \\
\hline Power factor & Relative units & 2.205 & 2,205 & 2,205 \\
\hline $\begin{array}{c}\text { Supply voltage } \\
\text { reverse sequence } \\
\text { coefficient }\end{array}$ & $\%$ & 6,37 & 6,107 & 6,37 \\
\hline $\begin{array}{c}\text { Coefficient of } \\
\text { curvature of the } \\
\text { sinusoid of the } \\
\text { supply voltage }\end{array}$ & $\%$ & & & \\
\hline
\end{tabular}




\subsection{Search for optimal values of the harmonic spectrum of the input voltage by a given criterion $\eta_{A M} \rightarrow$ max with given restrictions on the amplitudes of the harmonic components of the input voltage}

As is known ${ }^{47}$, at a sinusoidal supply voltage the direction and speed of rotation of the magnetizing forces of the stator and rotor coincide. In the presence of higher harmonics of direct phase alternation (4th, 7th, 10 th, 13 th,...$)$ the harmonic components of the stator field rotate in the same direction as the main harmonic component, with speeds less than the speed of the main harmonics respectively in $4,7,10,13, \ldots$ times. From the moment of start to the moment when the speeds of the harmonic components of the stator field become equal to the rotor speed, these harmonics create moments acting according to the moment of the main harmonic, and from the moment when their speeds become greater than the rotor speed - create moments, which are directed against the moment of the fundamental harmonic. The harmonic components of the stator field of the reverse phase alternation $(2 \mathrm{nd}, 5 \mathrm{th}, 8 \mathrm{th}, 11 \mathrm{th}, \ldots)$ rotate in the opposite direction with a speed less than the speed of the fundamental harmonic, respectively, in $2,5,8,11, \ldots$ times. They create moments that are always directed against the moment of the main harmonic.

According to the method ${ }^{48}$, we search for the optimal values of the harmonic spectrum of the input voltage according to the given criterion $\eta_{\mathrm{AM}} \rightarrow$ max under the given restrictions on the amplitudes of the harmonic components of the input voltage. As harmonics of influence we choose harmonics $\mathrm{k}=2 ; 5 ; 8 ; 11 ; 14$, because they cause the most damage to the induction motor.

According to ${ }^{49}$, the specified harmonic components of the supply voltage have normally acceptable values, given in table 3 .

${ }^{47}$ Бурбело М.И., Гадай А.В., Ильчук Ю.В. Математическое моделирование асинхронных двигателей в пусковых режимах в условиях несинусоидальности напряжения питания. Наукові пращі ВНТУ. 2011. № 1. С. 1-5.

48 Гребенникова, И.В. Методы оптимизации : учебное пособие Екатеринбург : УрФУ, 2017. 148 с.

49 ГОСТ 13109-97 Электрическая энергия. Совместимость технических средств электромагнитная. Нормы качества электрической энергии в системах электроснабжения общего назначения. URL : http://docs.cntd.ru/ document/1200006034 (дата звернення: 01.05.2020). 
Table 3

Normally acceptable values of the harmonic components of the supply voltage

\begin{tabular}{|c|c|c|c|c|c|}
\hline $\begin{array}{c}\text { № harmonic component } \\
\text { of supply voltage }\end{array}$ & 2 & 5 & 8 & 11 & 14 \\
\hline Normally a valid value, \% & $0 \ldots 2$ & $0 \ldots 6$ & $0 \ldots 0,5$ & $0 \ldots 3,5$ & $0 \ldots 0,2$ \\
\hline
\end{tabular}

Using a program that implements the Runge-Kutta method of order IV, we will search for the optimal values of the efficiency of an induction motor with given restrictions on the amplitudes of the harmonic components of the input voltage for normally acceptable values. During the simulation using the program, the integration step was $\mathrm{h}=1 \cdot 10^{-5}$. The number of processed points was $\mathrm{N}=4 \cdot 10^{5}$. The results of the calculations are shown in table 4 .

Table 4

The value of the efficiency of the AM at the specified limits on the amplitude of the harmonic components of the input voltage for the normally acceptable values

\begin{tabular}{|c|c|c|c|c|c|c|}
\hline $\begin{array}{c}\text { No } \\
\text { iterations }\end{array}$ & $\mathbf{K}_{\mathbf{U}(\mathbf{2})}, \boldsymbol{\%}$ & $\mathbf{K}_{\mathbf{U}(\mathbf{5})}, \boldsymbol{\%}$ & $\mathbf{K}_{\mathbf{U}(\mathbf{8})}, \boldsymbol{\%}$ & $\mathbf{K}_{\mathbf{U}(\mathbf{1 1})}, \boldsymbol{\%}$ & $\mathbf{K}_{\mathbf{U}(\mathbf{1 4})}, \boldsymbol{\%}$ & $\boldsymbol{\eta}$ \\
\hline $\mathbf{1}$ & $\mathbf{2}$ & $\mathbf{3}$ & $\mathbf{4}$ & $\mathbf{5}$ & $\mathbf{7}$ & $\mathbf{8}$ \\
\hline 1 & 0 & 0 & 0 & 0 & 0 & 0,7468 \\
\hline 2 & 0.04 & 0.12 & 0.01 & 0.07 & 0.004 & 0,7468 \\
\hline 3 & 0.08 & 0.24 & 0.02 & 0.14 & 0.008 & 0,7467 \\
\hline 4 & 0.12 & 0.36 & 0.03 & 0.21 & 0.012 & 0,7467 \\
\hline 5 & 0.16 & 0.48 & 0.04 & 0.28 & 0.016 & 0,7467 \\
\hline 6 & 0.2 & 0.6 & 0.05 & 0.35 & 0.02 & 0,7466 \\
\hline 7 & 0.24 & 0.72 & 0.06 & 0.42 & 0.024 & 0,7466 \\
\hline 8 & 0.28 & 0.84 & 0.07 & 0.49 & 0.028 & 0,7466 \\
\hline 9 & 0.32 & 0.96 & 0.08 & 0.56 & 0.032 & 0,7465 \\
\hline 10 & 0.36 & 1.08 & 0.09 & 0.63 & 0.036 & 0,7465 \\
\hline 11 & 0.4 & 1.2 & 0.1 & 0.7 & 0.04 & 0,7465 \\
\hline 12 & 0.44 & 1.32 & 0.11 & 0.77 & 0.044 & 0,7464 \\
\hline 13 & 0.48 & 1.44 & 0.12 & 0.84 & 0.048 & 0,7464 \\
\hline 14 & 0.52 & 1.56 & 0.13 & 0.91 & 0.052 & 0,7463 \\
\hline 15 & 0.56 & 1.68 & 0.14 & 0.98 & 0.056 & 0,7463 \\
\hline 16 & 0.6 & 1.8 & 0.15 & 1.05 & 0.06 & 0,7463 \\
\hline 17 & 0.64 & 1.92 & 0.16 & 1.12 & 0.064 & 0,7462 \\
\hline 18 & 0.68 & 2.04 & 0.17 & 1.19 & 0.068 & 0,7461 \\
\hline 19 & 0.72 & 2.16 & 0.18 & 1.26 & 0.072 & 0,7461 \\
\hline
\end{tabular}


Continuation Table 4

\begin{tabular}{|c|c|c|c|c|c|c|}
\hline $\mathbf{1}$ & $\mathbf{2}$ & $\mathbf{3}$ & $\mathbf{4}$ & $\mathbf{5}$ & $\mathbf{6}$ & $\mathbf{7}$ \\
\hline 20 & 0.76 & 2.28 & 0.19 & 1.33 & 0.076 & 0.7457 \\
\hline 21 & 0.8 & 2.4 & 0.2 & 1.4 & 0.08 & 0.7457 \\
\hline 22 & 0.84 & 2.52 & 0.21 & 1.47 & 0.084 & 0.7457 \\
\hline 23 & 0.88 & 2.64 & 0.22 & 1.54 & 0.088 & 0.7457 \\
\hline 24 & 0.92 & 2.76 & 0.23 & 1.61 & 0.092 & 0.7455 \\
\hline 25 & 0.96 & 2.88 & 0.24 & 1.68 & 0.096 & 0.7455 \\
\hline 26 & 1 & 3 & 0.25 & 1.75 & 0.1 & 0.7455 \\
\hline 27 & 1.04 & 3.12 & 0.26 & 1.82 & 0.104 & 0.7455 \\
\hline 28 & 1.08 & 3.24 & 0.27 & 1.89 & 0.108 & 0.7455 \\
\hline 29 & 1.12 & 3.36 & 0.28 & 1.96 & 0.112 & 0.7454 \\
\hline 30 & 1.16 & 3.48 & 0.29 & 2.03 & 0.116 & 0,7454 \\
\hline 31 & 1.2 & 3.6 & 0.3 & 2.1 & 0.12 & 0,7454 \\
\hline 32 & 1.24 & 3.72 & 0.31 & 2.17 & 0.124 & 0,7454 \\
\hline 33 & 1.28 & 3.84 & 0.32 & 2.24 & 0.128 & 0,7453 \\
\hline 34 & 1.32 & 3.96 & 0.33 & 2.31 & 0.132 & 0,7453 \\
\hline 35 & 1.36 & 4.08 & 0.34 & 2.38 & 0.136 & 0,7453 \\
\hline 36 & 1.4 & 4.2 & 0.35 & 2.45 & 0.14 & 0,7452 \\
\hline 37 & 1.44 & 4.32 & 0.36 & 2.52 & 0.144 & 0,7452 \\
\hline 38 & 1.48 & 4.44 & 0.37 & 2.59 & 0.148 & 0,7448 \\
\hline 39 & 1.52 & 4.56 & 0.38 & 2.66 & 0.152 & 0,7448 \\
\hline 40 & 1.56 & 4.68 & 0.39 & 2.73 & 0.156 & 0,7448 \\
\hline 41 & 1.6 & 4.8 & 0.4 & 2.8 & 0.16 & 0,7447 \\
\hline 42 & 1.64 & 4.92 & 0.41 & 2.87 & 0.164 & 0,7446 \\
\hline 43 & 1.68 & 5.04 & 0.42 & 2.94 & 0.168 & 0,7444 \\
\hline 44 & 1.72 & 5.16 & 0.43 & 3.01 & 0.172 & 0,7444 \\
\hline 45 & 1.76 & 5.28 & 0.44 & 3.08 & 0.176 & 0,7444 \\
\hline 46 & 1.8 & 5.4 & 0.45 & 3.15 & 0.18 & 0,7443 \\
\hline 47 & 1.84 & 5.52 & 0.46 & 3.22 & 0.184 & 0,7443 \\
\hline 48 & 1.88 & 5.64 & 0.47 & 3.29 & 0.188 & 0,7442 \\
\hline 49 & 1.92 & 5.76 & 0.48 & 3.36 & 0.192 & 0,7442 \\
\hline 50 & 1.96 & 5.88 & 0.49 & 3.43 & 0.196 & 0,7437 \\
\hline & & & & & & \\
\hline
\end{tabular}

According to the obtained calculations, the maximum value of the efficiency at the given restrictions on the amplitudes of the harmonic components of the input voltage for normally acceptable values corresponds to the first step of the iteration, where $\eta=0.7468$. 
According to ${ }^{50}$, the specified harmonic components of the supply voltage also have the maximum allowable values given in table 5 .

Table 5

Maximum allowable values of the harmonic components of the supply voltage

\begin{tabular}{|c|c|c|c|c|c|}
\hline $\begin{array}{c}\text { № harmonic } \\
\text { component of supply } \\
\text { voltage }\end{array}$ & 2 & 5 & 8 & 11 & 14 \\
\hline $\begin{array}{c}\text { Normally a valid } \\
\text { value, \% }\end{array}$ & $2 \ldots 3$ & $6 \ldots 9$ & $0,5 \ldots 0,75$ & $3,5 \ldots 5,25$ & $0,2 \ldots 0,3$ \\
\hline
\end{tabular}

Using a program that implements the Runge - Kutta method of order IV, we will search for the optimal values of the efficiency of an induction motor with given restrictions on the amplitudes of the harmonic components of the input voltage at the maximum allowable values. The results of the calculations are shown in table 6 .

Table 6

The value of the efficiency of the AM at the specified limits on the amplitude of the harmonic components of the input voltage for the maximum allowable values

\begin{tabular}{|c|c|c|c|c|c|c|}
\hline $\begin{array}{c}\mathbf{N} \mathbf{0} \\
\text { iterations }\end{array}$ & $\mathbf{K}_{\mathbf{U}(\mathbf{2})}, \boldsymbol{\%}$ & $\mathbf{K}_{\mathbf{U}(\mathbf{5})}, \boldsymbol{\%}$ & $\begin{array}{c}\mathbf{K}_{\mathbf{U}(\mathbf{8})}, \\
\mathbf{\%}\end{array}$ & $\begin{array}{c}\mathbf{K}_{\mathbf{U}(\mathbf{1 1})}, \\
\mathbf{\%}\end{array}$ & $\begin{array}{c}\mathbf{K}_{\mathbf{U}(\mathbf{1 4})}, \\
\mathbf{\%}\end{array}$ & $\boldsymbol{\eta}$ \\
\hline $\mathbf{1}$ & $\mathbf{2}$ & $\mathbf{3}$ & $\mathbf{4}$ & $\mathbf{5}$ & $\mathbf{6}$ & $\mathbf{7}$ \\
\hline 1 & 2 & 6 & 0,5 & 3,5 & 0,2 & 0,7435 \\
\hline 2 & 2,04 & 6,12 & 0,51 & 3,57 & 0,204 & 0,7435 \\
\hline 3 & 2,08 & 6,24 & 0,52 & 3,64 & 0,208 & 0,7435 \\
\hline 4 & 2,12 & 6,36 & 0,53 & 3,71 & 0,212 & 0,7433 \\
\hline 5 & 2,16 & 6,48 & 0,54 & 3,78 & 0,216 & 0,7433 \\
\hline 6 & 2,2 & 6,6 & 0,55 & 3,85 & 0,22 & 0,7433 \\
\hline 7 & 2,24 & 6,72 & 0,56 & 3,92 & 0,224 & 0,7432 \\
\hline 8 & 2,28 & 6,84 & 0,57 & 3,99 & 0,228 & 0,7431 \\
\hline 9 & 2,32 & 6,96 & 0,58 & 4,06 & 0,232 & 0,7426 \\
\hline 10 & 2,36 & 7,08 & 0,59 & 4,13 & 0,236 & 0,7425 \\
\hline 11 & 2,4 & 7,2 & 0,6 & 4,2 & 0,24 & 0,7425 \\
\hline
\end{tabular}

50 ГОСТ 13109-97 Электрическая энергия. Совместимость технических средств электромагнитная. Нормы качества электрической энергии в системах электроснабжения общего назначения. URL : http://docs.cntd.ru/ document/1200006034 (дата звернення: 01.05.2020). 
Continuation Table 6

\begin{tabular}{|c|c|c|c|c|c|c|}
\hline $\mathbf{1}$ & $\mathbf{2}$ & $\mathbf{3}$ & $\mathbf{4}$ & $\mathbf{5}$ & $\mathbf{6}$ & $\mathbf{7}$ \\
\hline 12 & 2,44 & 7,32 & 0,61 & 4,27 & 0,244 & 0,7424 \\
\hline 13 & 2,48 & 7,44 & 0,62 & 4,34 & 0,248 & 0,7424 \\
\hline 14 & 2,52 & 7,56 & 0,63 & 4,41 & 0,252 & 0,7423 \\
\hline 15 & 2,56 & 7,68 & 0,64 & 4,48 & 0,256 & 0,7423 \\
\hline 16 & 2,6 & 7,8 & 0,65 & 4,55 & 0,26 & 0,7422 \\
\hline 17 & 2,64 & 7,92 & 0,66 & 4,62 & 0,264 & 0,7422 \\
\hline 18 & 2,68 & 8,04 & 0,67 & 4,69 & 0,268 & 0,7421 \\
\hline 19 & 2,72 & 8,16 & 0,68 & 4,76 & 0,272 & 0,7415 \\
\hline 20 & 2,76 & 8,28 & 0,69 & 4,83 & 0,276 & 0,7413 \\
\hline 21 & 2,8 & 8,4 & 0,7 & 4,9 & 0,28 & 0,7413 \\
\hline 22 & 2,84 & 8,52 & 0,71 & 4,97 & 0,284 & 0,7412 \\
\hline 23 & 2,88 & 8,64 & 0,72 & 5,04 & 0,288 & 0,7411 \\
\hline 24 & 2,92 & 8,76 & 0,73 & 5,11 & 0,292 & 0,7398 \\
\hline 25 & 2,96 & 8,88 & 0,74 & 5,18 & 0,296 & 0,7397 \\
\hline
\end{tabular}

According to the obtained calculations, the maximum value of the efficiency at the given restrictions on the amplitudes of the harmonic components of the input voltage for the maximum allowable values corresponds to the first step of the iteration, where $\eta=0.7435$.

\section{CONCLUSIONS}

1. On the basis of existing literature sources were analyzed known mathematical models of induction motor with short-circuited rotor and their scope, identified their advantages and disadvantages. Studies have shown that the only model that takes into account all indicators of electricity quality (IEQ) at once, which would assess the energy efficiency of an electric machine, has not been found and the most flexible and universal option is to directly integrate differential equations describing AM.

2. The universal model of the induction motor developed by us allows to analyze static and dynamic processes in electromechanical system at non-sinusoidal and asymmetric pressure.

3. Approbation of the developed model by describing the start-up process, load sketch and set mode of the engine type MTKH 112-6 with 
a capacity of $5.3 \mathrm{~kW}$ using various methods of numerical integration proved that the most accurate calculation gives the Runge-Kutta method of the fourth order.

4. Studies conducted by the method of partial search on the synthesized mathematical analogue of an induction motor showed that the maximum value of the efficiency of an induction motor operating in a network with low-quality electricity is observed at minimum values of harmonic components in the case of normally allowable and maximum allowable values.

\section{SUMMARY}

It is well known that the negative impact of electricity with low quality on the performance of electric receivers. This is especially true of industrial electric drive systems, as its reliability and efficiency largely determine the technical and economic performance of many industries. In industrial conditions, the harmonious composition of the supply voltage and its symmetry depend on the modes of operation of powerful consumers, which have a negative impact on the electrical networks of enterprises, namely: rolling mills with thyristor converters, arc furnaces, galvanic baths and more. Scientific research shows that currently the indicators of electricity quality in enterprises, as a rule, do not meet the requirements. And this leads to an increase in the insulation temperature of the motors, and as a consequence, to a decrease in reliability and reduce their service life.

The aim of the monograph section is the synthesis of a mathematical analogue of an induction motor, which allows the company's staff to quickly assess the energy performance of an electromechanical converter operating in a network with low-quality electricity.

Research methods. In solving the research problems, probability theory, mathematical statistics, the theory of differential calculus, numerical integration, fundamental provisions of electrical engineering were used to compile mathematical models of an induction motor, and numerical optimization methods.

\section{REFERENCES}

1. Оценка влияния качества электроэнергии на эффективность электропотребления / В.В. Кузнецов, Е.В. Кузнецова, А.В. Кузнецова. Гірнича електромеханіка та автоматика. Науково-технічний збірник. 2018. Випуск 100. С. 85-95. 
2. $\alpha$-алгебра в задачах підвищення енергоефективності асинхронних двигунів, працюючих в умовах неякісної електроенергії / М.М. Трипутень, В.В. Кузнецов, С.В. Кузнецова, М.М. Трипутень, А.В. Кузнецова. Гірнича електромеханіка та автоматика. Науковотехнічний збірник. 2019. Випуск 101. С. 110-114.

3. Kuznetsov V., Tryputen N., Kuznetsova Y. Evaluating the Effect of Electric Power Quality upon the Efficiency of Electric Power Consumption // 2019 IEEE 2nd Ukraine Conference on Electrical and Computer Engineering (UKRCON), Lviv, Ukraine, 2019. pp. 556-561. doi: 10.1109/UKRCON.2019.8879841.

4. Predicative form of the energy-economic model of an asynchronous motor / M. Tryputen, V. Kuznetsov, Y. Kuznetsova, M. Tryputen, A. Kuznetsova, R. Sklyar. Системні технологіï. 2019. Вип. 2. С. 33-41.

5. Кузнецов В.В., Кузнецова А.В., Трипутень М.Н. Основные причины отклонения показателей качества электроэнергии от нормируемых. Енергозбереження та енергоефективність: зб. тез міжнар. наук.-практ. конф. (Дніпро. НТУ «ДП». 28-29 листопада 2019 р.). Дніпро, 2019. С. 12-13.

6. Кузнецов В.В. Кузнецова А.В., Трипутень М.Н. Количественная оценка показателей качества электроэнергии в цеховых сетях предприятий. Енергозбереження та енергоефективність : зб. тез міжнар. наук.-практ. конф. (Дніпро. НТУ «ДП». 28-29 листопада 2019 р.). Дніпро, 2019. С.14-15.

7. Кузнецов В.В. Трипутень Н.М. Кузнецова А.В., Трипутень М.Н. О нормировании показателей качества электроэнергии. Енергозбереження та енергоефективність: зб. тез міжнар. наук.-практ. конф. (Дніпро. НТУ «ДП». 28-29 листопада 2019 р.). Дніпро, 2019. С.16-17.

8. Serdiuk T., Kuznetsov V., Serdiuk K., Nikolenko A., Kuznetsova Y., Kuznetsova A. Improvement of Technical Service of Track Circuits. 2019 IEEE 6th International Conference on Energy Smart Systems, ESS 2019 - Proceedings, pp. 28-32. DOI: 10.1109/ESS.2019.8764191.

9. Characteristic layouts of distribution networks with the analysis of voltage deviations and expediency of its control / V. Kovalenko, S. Levchenko, M. Tryputen, V. Kuznetsov, M. Tryputen, O. Gorodny, A. Kuznetsova, Ye. Kuznetsova. Technical sciences and technologies. 2019. 3 (17). pp. 209-218.

10. United States Industrial Electric Motor Systems Market Opportunities Assessment December 2002. URL : 
https://www.energy.gov/sites/prod/files/2014/04/f15/mtrmkt.pdf. (дата звернення: 01.05.2020).

11. Annual Electric Power Industry Report, Form EIA-861 detailed data files. URL : https://www.eia.gov/electricity/data/eia861. (дата звернення: 01.05.2020).

12. Жаркин А.Ф., Палачев С.А. Нормативное регулирование качества электроэнергии в системах электроснабжения общего назначения Украины и стран Евросоюза. Технічна електродинаміка. 2007. № 6. C. 54-60.

13. Жаркин Л.Ф., Палачев С.А. и др. Нормативно-правовое регулирование вопросов качества электроэнергии в Украине и странах Евросоюза. Техн. електродинаміка. Тем. вип. "Силова електроніка та енергоефективність». 2007. Ч. 1. С. 74-77.

14. ГОСТ 13109-97 Электрическая энергия. Совместимость технических средств электромагнитная. Нормы качества электрической энергии в системах электроснабжения общего назначения. URL : http://docs.cntd.ru/document/1200006034 (дата звернення: 01.05.2020).

15. Кузнецов В.В., Трипутень Н.М., Кузнецова А.В., Трипутень М.Н. Динамическая электромагнитная модель асинхронного двигателя, работающего в условиях некачественной электроэнергии. Матеріали Міжнародної науково-технічної конференції Інформаційні технологї в металургії та машинобудуванні. 26-28 березня 2019 року м. Дніпро. С. 87.

16. Beaty H. Motors reguire voltage limits. Elec.World. Vol. 189. No. 5.1978. P. 52-53.

17. Shaller D.,Seidler E. Berechnung des Einflusses einer Zweiphasenlast auf die Strom - und Spannungsunsymmetrie in Energieversorgungsnetzen // Mitt.Inst.Energ. H. 70. 1965. S. 586-596.

18. Марданов Фарит Халитович Показатели качества электроэнергии, влияющие на работу электрооборудования города. Проблемы науки. 2018. № 5(29). URL : https://cyberleninka.ru/article/ n/pokazateli-kachestva-elektroenergii-vliyayuschie-na-rabotuelektrooborudovaniya-goroda (дата обращения: 02.05.2020).

19. Луговой А.В. Вопросы практического энергосбережения промышленных предприятий. Вісник КДПУ. 1998. Випуск 1(4). C. $73-77$.

20 Зиновкин В.В. Моделирование добавочных потерь в электрооборудовании системы электротехнического комплекса при несинусоидальных токах. Вісник КДПУ. Випуск 4/2007(45). С. 49-52. 
21. Energiesparen mit elektrischen Antrieben. - Frankfurt am Main: Zentral-verband Elektrotechnik- und Elektronikindustrie e.V. 2007. S. 24.

22. Motoren und geregelte Antriebe. - Frankfurt am Main: Zentralverband Elektrotechnik- und Elektronikindustrie e.V. 2010. S. 16.

23. Кузнецов В.В., Трипутень Н.М., Кузнецова А.В., Трипутень М.Н. Разработка динамической электромагнитной модели асинхронного двигателя, работающего в условиях некачественной электроэнергии. Матеріали Міжнародної науковотехнічної конферениії Інформаційні технології в металургії та машинобудуванні. 26-28 березня 2019 року м. Дніпро. С. 88.

24. Кузнецова А.В., Сердюк Т.М. Електромагнітна сумісність пристроїв залізничної автоматики 3 системою тягового електропостачання. Сучасні інформаційні та комунікаційні технології на транспорті, в промисловості $i$ освіті: Тези ХII Міжнародної науково-практичної конферениії (Дніпро, 12-13 грудня 2018 р.). Дніпро : ДНУЗТ, 2018. С. 37.

25. Kuznetsov V., Kuznetsova A., Truputen M. Dynamic electromagnetic model of asynhronous motor operating in terms of poorquality electric power. Компьютерне моделювання та оптимізаиія складних систем (КМОСС-2019): матеріали V Міжнародної науково-технічної конференції (м. Дніпро, 6-8 лтстопада 2019). Дніпро : Баланс-Клуб, 2019. С. 74-75.

26. Копылов И.П. Математическое моделирование электрических машин. Москва : Наука, 2001. 327 с.

27. Ковач К. Переходные процессы в машинах переменного тока. Москва-Ленинград : Госэнергоиздат, 1963. 744 с.

28. Оценка качества преобразования энергии в электрических машинах с учетом параметров питающего напряжения / А.П. Черный, А.П. Калинов, В.А. Киричков. Вісник КДПУ. 2007. Випуск 4/2007 (45). Частина 1. С. 67-69.

29. Определение послеремонтной паспортной мощности асинхронного двигателя с короткозамкнутым ротором / Д.И. Родькин, И.Н. Здор, В.В. Прус. Проблемь создания новых машин и технологий. Сб. научных трудов КГПИ. 2000. Выпуск 1/2000 (8). С. 65-71.

30. Эквивалентизация потерь асинхронных двигателей при динамическом нагружении / Д.И. Родькин, В.А. Мосьпан. Проблемы создания новых машин и технологий. Сб. научных трудов КГПИ. 2000. Выпуск 1/2000(8). С. 96-107. 
31. Математическая модель для исследования трехфазного асинхронного двигателя с короткозамкнутым ротором как объекта регулирования им для прямого процессорного управления / Т.В. Войнова. Электротехника. 1998. № 6. С. 51-61.

32. Программное обеспечение для моделирования трехфазного асинхронного двигателя с короткозамкнутым ротором в составе системы управления электроприводами и для бездатчикового измерения регулируемых переменных / Т.В. Войнова. Электротехника. 2000. № 1. С. 19-25.

33. Анализ точности математической модели трехфазного асинхронного двигателя / В.Г. Макаров. Изв. вузов: Проблемы энергетики. Казань : КГЭУ. 2010. № 11-12. С. 115-125.

34. Анализ методов учета нелинейности магнитопровода и потерь в стали в математической модели асинхронного двигателя / В.Г. Макаров, В.А. Матюшин. Вестник Казан. технол. ун-та. 2010. № 11. C. 171-179.

35. Оптимальное управление токами электрических машин / В.Г. Макаров, В.А. Матюшин. Вестник Казан. технол. ун-та. Казань : КГЭУ. 2010. № 11. С. 186-195.

36. Иванов-Смоленский А.В. Электрические машины. В 2-х т. Том 1: Учебник для вузов. 2-е изд., перераб. и доп. Москва : Издательство МЭИ, 2004. 656 с.

37. Копылов И.П. Щедрин О.П. Расчет на ЦВМ характеристик асинхронных машин. Москва : Энергия. 1973. 212 с.

38. Бессонов Л.А. Теоретические основы электротехники. Электрические цепи : учебник. 11-е изд., перераб. и доп Москва : Гардарики, 2007. $701 \mathrm{c.}$

39. Kuznetsova Ye., Kuznetsov V., Tryputen M., Kuznetsova A., Tryputen M., Babyak M. Development and Verification of Dynamic Electromagnetic Model of Asynchronous Motor Operating in Terms of Poor-Quality Electric Power. Proceedings of the International Conference on Modern Electrical and Energy Systems, MEES 2019. pp. 350-353. DOI: 10.1109/MEES.2019.8896598.

40. Оценка нелинейности индуктивности катушки со сталью энергетическим методом / В.А. Огарь. Вестник КрГПУ. 2004. Вып. 2/2004 (25). С. 78-84.

41. Вешеневский С.Н. Характеристики двигателей в электроприводе. Изд. 6-е, исправленное. Москва : Энергия, 1977. 431c. 
42. ГОСТ 7217-87 «Машины электрические вращающиеся. Двигатели асинхронные. Методы испытаний».

43. Kerkman O, Russel J. Steady-State and Transient Analyses of an Induction Machine with Saturation of the Magnetizing Branch. IEEE Transactions on Industry Applications. 1985. Vol. 21. P. 226-234.

44. Башарин А.В. Постников Ю.В. Примеры расчета автоматизированного электропривода на ЭВМ : учебное пособие для вузов. 3-е изд. Ленинград : Энергоатомиздат, Ленинградское отд-ние. 1990. $210 \mathrm{c}$.

45. Бойко Л.Т. Основи чисельних методів. Навчальний посібник. Дніпропетровськ : Видавництво ДНУ. 2009. 244 с.

46. Бурбело М.И., Гадай А.В., Ильчук Ю.В. Математическое моделирование асинхронных двигателей в пусковых режимах в условиях несинусоидальности напряжения питания. Наукові праці ВНТУ. 2011. № 1. С. 1-5.

47. Гребенникова, И.В. Методы оптимизации : учебное пособие Екатеринбург : УрФУ, 2017. 148 с.

\section{Information about authors:} Kuznetsova Ye. V.,

Senior Lecturer at the Department of Humanitarian, Fundamental and General Engineering Disciplines Educational-Scientific Institute of the Integrated Education of National Metallurgical Academy of Ukraine 4, Gagarin avenue, Dnipro, 49000, Ukraine

Kuznetsova A. V., Student at the Department of Calculating Mathematics and Mathematical Cybernetics Oles Honchar Dnipro National University 35, Dmytro Yavornytskoho avenue, Dnipro, 49000, Ukraine 